\section{Exploring entrepreneurial characteristics, motivations and behaviours in equity crowdfunding: some evidence from Italy}

Exploring entrepreneurial characteristics in $\mathrm{ECF}$

Ciro Troise

Department of Management, Università degli Studi della Campania Luigi Vanvitelli, Capua, Italy, and Mario Tani

Department of Economia, Management, Istituzioni, Università degli Studi di Napoli Federico II, Napoli, Italy

\begin{abstract}
Purpose - This study explores entrepreneurial decision-making in the equity crowdfunding (ECF) context, and it aims to shed some light on the relationship among three aspects: entrepreneurial characteristics (i.e. entrepreneurial alertness and entrepreneurial self-efficacy), entrepreneurial motivations (i.e. promotion, improvement of networking and acquisition of product and market knowledge) and entrepreneurial behaviours (i.e. campaign characteristics in terms of communication and offerings).

Design/methodology/approach - The hypotheses testing and analysis were conducted using the partial least squares approach to structural equation modelling, and data were collected from the overall population of Italian ECF platforms.

Findings - Our results highlight that entrepreneurial characteristics may be central in ECF because of their significant impact on some motivation entrepreneurs have to adopt ECF, which in turn have an impact on meaningful campaign characteristics that can influence ECF performance.

Originality/value - The current literature is mainly focused on investors' decisions, while a neglected perspective until now has been that of entrepreneurs. This study is among the first to focus on entrepreneurs in the ECF context, and, to the best of our knowledge, it is the first study to investigate the entrepreneurial decision-making process. The added value of this research lies in the analysis of the entrepreneurial aspects underlying entrepreneurial decisions to use ECF.
\end{abstract}

Keywords Entrepreneurial decision-making, Entrepreneurial motivation, Entrepreneurial behaviour, Equity crowdfunding

Paper type Research paper

\section{Introduction}

Decision-making is central to the success, longevity and survival of entrepreneurial activities (Caputo and Pellegrini, 2019). It is a well-established topic of interest in several fields, particularly management, but there is still a paucity of studies on entrepreneurial decisionmaking (EDM) (Shepherd et al., 2015), although EDM is deeply influenced by the evolution and turbulence of the modern global landscape (e.g. new ideas coming out of Fintech, digital platforms, iot or AI) (Cohen et al., 2017; Li et al., 2018; Agostini and Nosella, 2019; Balodi, 2019; Bullini Orlandi and Pierce, 2020). Given the emphasis on making decisions in uncertain contexts (Pellegrini and Ciappei, 2015), such as crowdfunding (Xu et al., 2015), equity crowdfunding (ECF) is emerging as an intriguing research area within the sphere of

(C) Ciro Troise and Mario Tani. Published by Emerald Publishing Limited. This article is published under the Creative Commons Attribution (CC BY 4.0) licence. Anyone may reproduce, distribute, translate and create derivative works of this article (for both commercial and non-commercial purposes), subject to full attribution to the original publication and authors. The full terms of this licence may be seen at http://creativecommons.org/licences/by/4.0/legalcode
Received 15 October 2019 Revised 23 February 2020 1 April 2020

Accepted 6 April 2020 
entrepreneurship (Cholakova and Clarysse, 2015; McKenny et al., 2017) and in particular EDM (Bruton et al., 2015; Shepherd and Patzelt, 2017). ECF is a fundraising system for entrepreneurs (Ahlers et al., 2015; Vulkan et al., 2016) to sell a specified amount of equity to several small investors through an open call on an Internet-based platform, and it helps entrepreneurs in catching opportunities and in developing or growing their business.

ECF platforms allow entrepreneurs to finance their initiatives directly from the crowd and tap into its "wisdom" (Belleflamme et al., 2014; Polzin et al., 2018). The potential to attract unrelated investors - i.e. ones other than family members, friends or local businesses - is crucial to inducing entrepreneurs to seek external equity (Baeck et al., 2014; Vismara, 2018) and raise the necessary funds to achieve their goals, such as internationalisation, testing new products, brand development or building a loyal customer base (Estrin et al., 2018). ECF helps entrepreneurs get around the post-2008 crisis (Kunc and Bhandari, 2011) reduction in funds from banks, venture capitalists (VCs) and business angels (BAs) (Kahle and Stulz, 2013; Bruton et al., 2015; Vulkan et al., 2016; Block et al., 2018a).

The global crowdfunding market size will grow by US $\$ 89.72$ billions during 2018-2022 (Technavio, 2018). ECF has exhibited one of the fastest annual growth rates in the last few years; in fact, its volume has nearly doubled every year, from 392 million dollars in 2013 to over 4 billion dollars in 2016 (Massolution, 2016). As a consequence, several countries and regulatory authorities have introduced new laws or specific regulations affecting ECF. In this vein, Italy is one of the most important cases, considered of international interest since it is a pioneer in regulating ECF and creating a specific public national registry (Vismara, 2016; Piva and Rossi-Lamastra, 2018; Rossi and Vismara, 2018; Feola et al., 2019).

Research on ECFs is still in its infancy, and scholarly knowledge remains limited and fragmented. Among the promising directions for further advancements in ECF research, the perspective of entrepreneurs is one of the least explored (Mochkabadi and Volkmann, 2018). The literature mainly focuses on investors' decisions and on campaigns' success factors (Ahlers et al., 2015; Lukkarinen et al., 2016; Vismara, 2016; Block et al., 2018b; Polzin et al., 2018; Stevenson et al., 2019), while little is known of why entrepreneurs decide to use ECF as they can adopt ECF not only to get financial resources (Di Pietro et al., 2018; Estrin et al., 2018; Wald et al., 2019).

Understanding why entrepreneurs enter in ECF is a relevant idea, even if it is mostly neglected in the literature, as the entrepreneur, his behaviour and what he decides to disclose in an ECF campaign are meaningful factors in improving the campaign's success (Ahlers et al., 2015; Cholakova and Clarysse, 2015; Lukkarinen et al., 2016; Vismara, 2016, 2018; Block et al., 2018b; Polzin et al., 2018; Stevenson et al., 2019).

We adopted the partial least squares approach to structural equation modelling (PLSSEM) to try to shed some light on these topics and provide an in-depth analysis of the relationship among the entrepreneur' $\mathrm{s}$ characteristics, his motivations and the related behaviours in an ECF campaign. We looked at two well-known entrepreneurial characteristics - entrepreneurial alertness (EA) (Tang et al., 2012; Gaglio and Winter, 2017a, b; Obschonka et al., 2017; Adomako et al., 2018; Roundy et al., 2018; Neneh, 2019; Patel, 2019; Sharma, 2019; Chen et al., 2020) and entrepreneurial self-efficacy (ESE) (Zhao et al., 2005; Günzel-Jensen et al., 2017; Hsu et al., 2017; Mauer et al., 2017; Miao et al., 2017; Schjoedt and Craig, 2017; Brändle et al., 2018; Schmitt et al., 2018; Stroe et al., 2018; McGee and Peterson, 2019; Schmutzler et al., 2019; Shahab et al., 2019) - as both may influence the entrepreneur's actions and his or her opportunity recognition. These characteristics lead entrepreneurs to define a specific strategy, search for specific elements or satisfy particular needs, such as a lack of knowledge in a field. Therefore, we first explored how they may affect entrepreneurial motivations in terms of what resources entrepreneurs are looking to get out of ECF (e.g. product and market knowledge (PMK), networking resources (NET) or promotion of his or her business idea (PR)) (Di Pietro et al., 2018; Estrin et al., 2018). Second, we considered the 
influence of these motivations on entrepreneurial behaviours - i.e. which characteristics they choose for their campaigns (both in terms of campaign communication and offerings, respectively CCC and COC) (Lukkarinen et al., 2016) - as they depend on entrepreneurs' goals and reflect their intentions (e.g. acquiring new market/strategy knowledge, co-creating products, fostering their company's public awareness or exploiting a crowd network) and affect the ECF performance. Finally, we looked at how these behaviours may predict ECF performance, i.e. the outcomes of the campaign.

The paper is structured as follows. In the next section, we provide the theoretical background, then we develop the research hypotheses. In the following section, we describe the research methodology used to conduct the study, which includes a description of data and variables. We then present and discuss the findings of our research and their theoretical and practical implications. In the last section we highlight the research limitations and give some suggestions for further research.

\section{Theoretical background}

It is well known that EDM influences strategy, and it requires strategic thinking (Vermeulen and Curseu, 2008; Yagnik and Chandra, 2019). Vermeulen and Curseu (2008, p. 16) highlighted the importance of a strategic EDM process and that it leads to the choice of stepwise activity and how these steps are executed to derive a probable desired solution. In this regard, Yagnik and Chandra (2019, p. 11) argued that "decision-making in itself is a strategic activity, which counts for determining a specific course of action to reach the desired strategic goals".

The EDM process is a complex phenomenon (Shane, 2000). Entrepreneurs have a unique "entrepreneurial mindset", prompting them to search for the best opportunities to pursue (McGrath and MacMillan, 2000; Sassetti et al., 2019). Entrepreneurial characteristics play a key role in identifying and exploiting opportunities (Ucbasaran et al., 2009). Even the entrepreneurs' motivations are considered a significant aspect. In fact, entrepreneurial motivations in EDM are meaningful for business success and survival (Baum and Locke, 2004).

At the same time, different entrepreneurs will look at the same situation in different ways, making different evaluations (Shane, 2000; Pellegrini and Ciappei, 2015). Entrepreneurs have to find wisdom under blurred conditions (Pellegrini and Ciappei, 2015, p. 769) when discovering, or defining, a new opportunity (Shane, 2000; Welter and Alvarez, 2015; Bayon et al., 2016) and when they have to make choices (Rosenzweig, 2013).

In recent years, crowdfunding has become a strategic choice for entrepreneurs and a significant alternative to traditional financing systems (Ahlers et al., 2015; Xu et al., 2015; Vulkan et al., 2016). ECF has three main advantages for entrepreneurs: they can make an open call for investors online, limiting an otherwise time-consuming search process (Schwienbacher and Larralde, 2012); they can choose the amount of equity offered to limit their loss of ownership and control (Ahlers et al., 2015; Vismara, 2016) and they can sell to many small investors -i.e. the crowd - instead of few and big ones (Belleflamme et al., 2014; Ahlers et al., 2015).

A growing number of entrepreneurs have started to approach ECF strategically not only to get funds but also to engage the crowd to get publicity and contacts (Macht and Weatherston, 2014; Di Pietro et al., 2018). At the same time, entrepreneurs may exploit ECF to obtain other resources or to fill knowledge gaps (e.g. specific markets or products) (Belleflamme et al., 2014; Schwienbacher, 2018).

Crowdfunding also represents a form of crowdsourcing (Lambert and Schwienbacher, 2010; Schwienbacher and Larralde, 2012; Liu et al., 2016; Di Pietro et al., 2018), where entrepreneurs obtain feedback from the crowd, which can help to develop or test new product/service ideas prior to launch. A large crowd of investors enables entrepreneurs to benefit from the "wisdom of crowds" - i.e. the collective skills and knowledge of the investors (Belleflamme et al., 2014; Polzin et al., 2018) - giving them useful insights.
Exploring entrepreneurial characteristics in $\mathrm{ECF}$ 
$\mathrm{MD}$

59,5

\section{8}

ECF may be particularly helpful for entrepreneurs without a track record as they are less attractive to traditional investors (e.g. banks, VCs or BAs) (Collins and Pierrakis, 2012). The crowd creates hype around a business, generates public exposure for it and its products/ services and raises awareness (Lambert and Schwienbacher, 2010; Belleflamme et al., 2014; Di Pietro et al., 2018). This may result in more exposure to more investors, facilitating future access to further capital.

In the last few years, ECF has been studied by several scholars. Most of these studies have focused on the drivers of campaigns' success in terms of equity sold and investors involved (Ahlers et al., 2015; Cholakova and Clarysse, 2015; Lukkarinen et al., 2016; Vismara, 2016, 2018; Block et al., 2018b; Polzin et al., 2018; Stevenson et al., 2019); other studies have focused on the choice of determinant campaign characteristics and how they influence investor decisions and, thus, the success of campaigns (Ahlers et al., 2015; Lukkarinen et al., 2016; Vismara, 2016; Vulkan et al., 2016; Block et al., 2018b). Feola et al. (2019) specifically explored the Italian ECF scenario and suggested that ECF investors are not similar; in fact, they found four distinct types of investors, characterised by different behaviours in their investment actions ("venture trustful", "crowdfunding technicians", "financial investors, talent scouters" and "social dreamers"). The scholars suggested that entrepreneurs should adopt a marketing perspective in raising capital for their companies and segment potential investors by leveraging specific strategies "aimed to promote investment opportunities to match the diverse investor segments" (Feola et al., 2019, p. 13).

Entrepreneurial motivations drive the choice of campaign characteristics to meet specific goals (Di Pietro et al., 2018; Estrin et al., 2018). Only a few studies have considered that ECF is more than a fundraising tool (Di Pietro et al., 2018; Estrin et al., 2018; Wald et al., 2019). ECF platforms allow the provision of resources, knowledge and services that have become accessible to hundreds of equity funders drawn from a public crowd (Di Pietro et al., 2018), while past research (Gormon and Sahlman, 1989; MacMillan et al., 1989; Macht and Robinson, 2009) shows that these elements derive from the intense private relationships between entrepreneurs and a limited number of experienced professional investors (e.g. VCs and BAs).

The entrepreneurs' perspective and their behaviour before a campaign launch are still not fully studied. Different entrepreneurs may have different characteristics and motivations. Their characteristics affect their decisions whether or not to engage in new contexts (such as an open innovation (OI) context), search for innovations or strategically approach new mechanisms to obtain further resources or input from the crowd by leveraging external knowledge and thus benefiting from external sources of innovation (Ucbasaran et al., 2008; Tang et al., 2012; Du et al., 2016; Di Pietro et al., 2018).

\section{Hypotheses development \\ Entrepreneurial alertness}

EA is central in the EDM process. EA, according to Kirzner $(1973,1979)$, is the entrepreneur's ability to identify opportunities usually overlooked by others. It is a key feature of the emerging entrepreneurial mindset (Obschonka et al., 2017). Entrepreneurs are open to opportunities (Renko et al., 2012), they are more alert to new entrepreneurial ventures (Busenitz, 1996; Tang et al., 2012) and they are more effective in acknowledging, and exploiting, new opportunities (Shane and Venkataraman, 2000; Maine et al., 2015; Gaglio and Winter, 2017a, b; Neneh, 2019; Sharma, 2019). This opportunity recognition (Wang et al., 2013) builds on a state of heightened alertness to new information, and entrepreneurs pay constant attention to the environment (Lumpkin and Lichtenstein, 2005; Valliere, 2013). Entrepreneurs exhibit high alertness by investigating new opportunities through a continuous search for information and a broad scanning at unconventional times and places (Kaish and Gilad, 1991; Gaglio and Katz, 2001). Ardichvili et al. (2003, p. 105) defined EA as "a necessary condition for the success of the opportunity identification triad: recognition, development, and evaluation". 
Tang et al. (2012) suggested that alert entrepreneurs are likely to increase their companies' innovations since they perceive trends and their consequences more accurately than nonalert ones (Gaglio and Katz, 2001); they are more effective at exploiting external resources and at pursuing new opportunities (Van Den Bosch et al., 1999; Gray, 2006; Patel, 2019; Chen et al., 2020).

Roundy et al. (2018) suggested that if decision-makers are entrepreneurially alert they are more ready to make strategic change decisions that lead them to subsequent entrepreneurial opportunities. The scholars argue that EA is influential because alert entrepreneurs make rapid and nimble decisions and are, therefore, more likely to earn first-mover advantages.

Furthermore, EA leads entrepreneurs to be more open and to leverage new tools (Busenitz, 1996; Tang et al., 2012). OI platforms are among the most relevant mechanisms; in fact, more and more entrepreneurs engage in OI contexts (Chesbrough, 2003; Reed et al., 2012; Hsieh et al., 2016; Gomezel and Rangus, 2018) in order to increase opportunities for their firms and their innovations (Bayon et al., 2016). In this vein, OI practices are useful mechanisms for entrepreneurs to leverage external knowledge and to accelerate internal innovation and commercialisation opportunities (Chesbrough, 2003; Du et al., 2016). Di Pietro et al. (2018) held that ECF platforms are an important example of OI platforms because entrepreneurs can get both financial resources and support from the wisdom of the crowd; at the same time, the scholars highlighted that entrepreneurs' characteristics influence their motivation to resort to an OI tool like ECF.

Moreover, several studies in the EDM literature have suggested that EA is most salient when decision-makers must respond to a specific scenario or to a disruption in their environment (Hitt et al., 2001; Roundy et al., 2018). In the last few years, ECF has represented a disruptive innovation in funding markets as it shifts the focus to the crowd (Belleflamme et al., 2014; Ahlers et al., 2015; Bruton et al., 2015). Accordingly, many entrepreneurs have started using ECF for their projects as an alternative solution to traditional funding (Kahle and Stulz, 2013; Bruton et al., 2015; Vulkan et al., 2016; Block et al., 2018a).

In line with prior studies, we suggest that EA allows for better entrepreneurial opportunities. In line with this, EA leads entrepreneurs to search for new resources from a new system like ECF and get superior performance. In particular, in ECF a high level of EA should influence the motivation to launch an online call, and it should drive entrepreneurs to search for new useful resources (not only the financial ones) by engaging the crowd. Accordingly, we define our first hypothesis as follows:

\section{H1. EA has positive effects on entrepreneurial motivations to resort to ECF.}

Entrepreneurs adopt ECF not only to get financial resources but also to leverage other, more relational resources useful in seizing new opportunities (Ebbers, 2014). Pryor et al. (2016, p. 27) argued that entrepreneurs recognise actual "opportunities and find solutions by defining feedback-seeking and evaluation behaviours".

Alert entrepreneurs will participate in ECF to get several benefits by leveraging external sources from the crowd. EA will lead entrepreneurs to search for product co-creation activities - e.g. getting feedback or suggestions from the crowd to develop more customised products/services or involving investors as testers - or receive market advice - i.e. getting insights from the crowd about market trends, potential competitors or partners and so on (Di Pietro et al., 2018).

Alert entrepreneurs are more likely to search for more connections (Adomako et al., 2018) and exploit a crowd-network (Di Pietro et al., 2018). Active participation in the ECF mechanism gives entrepreneurs the opportunity to grow their networks since the investors will help build the company's network, creating new connections with external stakeholders (Di Pietro et al., 2018). Moreover, a high number of connections positively increase the probability of receiving outside financing (Vismara, 2016).

\section{Exploring entrepreneurial characteristics in $\mathrm{ECF}$}

999 
$\mathrm{MD}$

59,5

1000

Finally, EA induces entrepreneurs to improve the promotion of their business and search for external resources to foster it. Thus, entrepreneurs leverage a crowd's contacts to promote their businesses and improve word of mouth. Furthermore, they enhance their company's external visibility through crowd ambassadors, who increase public awareness by acting as marketing channels (Di Pietro et al., 2018).

To understand these different effects, in this study we investigated the relationship between EA and each of the three categories of entrepreneurial motivation - PMK, NET and $\mathrm{PR}$ - and have therefore defined the following sub-hypotheses:

H1a. EA has a positive effect on searching for PMK from an ECF campaign.

H1b. EA has a positive effect on searching for NET from an ECF campaign.

H1c. EA has a positive effect on searching for PR from an ECF campaign.

Entrepreneurial self-efficacy

ESE is a specific form of self-efficacy (Chen et al., 1998) affecting an entrepreneur's choice of activities, goals and performance (Zhao et al., 2005). It has been studied in many fields, particularly social psychology, to explain human behaviours, motivations and performance (Gist and Mitchell, 1992; Bandura, 1997; Mauer et al., 2017), and it plays an influential role in determining choices, level of effort and perseverance (Chen et al., 2004).

Over the years, interest in ESE has grown significantly in the field of entrepreneurship, particularly EDM (Günzel-Jensen et al., 2017; Brändle et al., 2018; Schmitt et al., 2018; Stroe et al., 2018; Schmutzler et al., 2019; Shahab et al., 2019). In fact, the literature on entrepreneurship highlights several studies that leveraged ESE to explore entrepreneurial success/failure or firm performance (Hsu et al., 2017; Miao et al., 2017; Schjoedt and Craig, 2017; McGee and Peterson, 2019).

ESE has been seen as a predictor of entrepreneurial intentions and a useful element in driving toward creating new entrepreneurial activities (Zhao et al., 2005; Barbosa et al., 2007; McGee et al., 2009). Chen et al. (1998, p. 295) reported that "ESE refers to the strength of a person's belief that he or she is capable of successfully performing the various roles and tasks of entrepreneurship. It consists of five factors: marketing, innovation, management, risktaking, and financial control”.

ESE is linked to how an entrepreneur perceives his or her own capability to accomplish a task (Bandura, 1986; Lindsley et al., 1995); it produces its effects through motivational processes (Bandura, 1977). Chen et al. (1998) suggested that ESE can be used to identify several reasons for entrepreneurial avoidance, i.e. not engaging in specific contexts or mechanisms. Forbes (2005) argued that the level of ESE affects the extent of entrepreneurs' comprehensive decision-making. Entrepreneurs with a high level of ESE do not search for new input, such as for marketing or innovation.

ESE leads to optimism, and entrepreneurs with high ESE hold strong beliefs in their entrepreneurial abilities (Krueger and Brazeal, 1994; Chen et al., 1998; Ardichvili et al., 2003; Forbes, 2005). Accordingly, we assume that high levels of ESE will have a negative impact on entrepreneurial motivation to use ECF as a way to get new (but not financial) resources - the entrepreneur's confidence in his capabilities will hinder the opportunity identification process and work against the search for new inputs (Zhao et al., 2005; Drnovšek et al., 2010). Accordingly, we define our second hypothesis as follows:

H2. ESE has a negative impact on entrepreneurial motivations to resort to ECF.

Entrepreneurs with high ESE do not aim to leverage an OI mechanism like ECF to get crowd input since they do not consider them of primary importance and prefer to rely on their own knowledge (Ucbasaran et al., 2008). We suggest that the higher the ESE level, the lower the 
level of ECF use by the entrepreneur to obtain new crowd input on each of the three dimensions of entrepreneurial motivation (PMK, NET and PR). A high level of ESE, in fact, could lead entrepreneurs to avoid asking the crowd for new knowledge on products or markets, to avoid leveraging funders to grow their networks and to not exploit them in promoting the company and its products/services. Accordingly, we define three subhypotheses as follows:

H2a. ESE has a negative effect on searching for PMK from an ECF campaign.

Exploring entrepreneurial characteristics in $\mathrm{ECF}$

$H 2 b$. ESE has a negative effect on searching for NET from an ECF campaign.

H2c. ESE has a negative effect on searching for PR from an ECF campaign.

\section{Entrepreneurial motivations to use ECF}

Several studies have explored investors' motivations to use ECF (Ahlers et al., 2015; Cholakova and Clarysse, 2015; Block et al., 2018b; Polzin et al., 2018), while entrepreneurs' ones are still less investigated (Mochkabadi and Volkmann, 2018). According to several scholars (Belleflamme et al., 2014; Estrin et al., 2018), even if the main reason to use ECF is to get financial resources, there are other motivations, such as getting known, getting feedback and several other advantages to help company growth and development. These studies have shown that ECF allows entrepreneurs to test their products, develop their brand and build a loyal customer base, while turning customers into investors.

Di Pietro et al. (2018) studied ECF platforms as OI platforms and found that those companies exploiting the crowd network - to get input on products, strategies and other market knowledge - were more successful than the others.

Wald et al. (2019) examined non-financial benefits of ECF campaigns and found that the crowd could offer entrepreneurs both inward benefits (investors' experiences and expertise) and outward benefits (public exposure and investor recruitment).

In this study we propose that entrepreneurs leverage ECF as a way to get access to various useful resources (Barney, 2001; Meyer, 2019). Lukkarinen et al. (2016) argued that as a campaign's characteristics can be predetermined by the entrepreneur prior to the campaign, they are related to entrepreneurs' motivations and goals. Accordingly, entrepreneurs disclose and define the campaign characteristics based on their specific motivations, so we define our third hypothesis as follows:

H3. Entrepreneurial motivations affect the choice of campaign characteristics.

Consistent with the previous literature (Di Pietro et al., 2018; Estrin et al., 2018), we focus on several key parameters: the acquisition of new knowledge on products and markets (e.g. feedback on products or internationalisation strategies), the improvement of networking resources (to become more connected with other relevant stakeholders or improve the usefulness of their contacts) and more effective business promotion (leveraging the crowd as business ambassadors or as a source of positive word of mouth). We assume that entrepreneurial motivations determine ECF campaign characteristics both in terms of CCC (social networks, images and updates) and COC (equity offered and funding target).

We hypothesise that non-financial motivations negatively influence COC, as entrepreneurs set a lower target (i.e. equity offered and funding target) to engage a large number of small investors (Vismara, 2016). Accordingly, we define the following three subhypotheses:

H3a. PMK motivations have a negative effect on COC.

$H 3 b$. NET motivations have a negative effect on COC. 
However, we expect a positive impact for CCC, as PMK, NET and PR lead entrepreneurs to post more information, more updates and/or more images and the links to their social network profiles to deeply engage the crowd (Bretschneider and Leimeister, 2017; Block et al., 2018b). Entrepreneurs leverage several tools and disclose some specific elements useful to improve crowd knowledge (Ahlers et al., 2015; Vismara, 2016; Block et al., 2018b). Therefore, we propose the following three sub-hypotheses:

H3d. PMK motivations have a positive effect on CCC.

H3e. NET motivations have a positive effect on CCC.

H3f. PR motivations have a positive effect on CCC.

\section{Campaign characteristics}

In the academic literature, several campaign characteristics have been used as predictors of ECF success (Ahlers et al., 2015; Lukkarinen et al., 2016; Vismara, 2016; Vulkan et al., 2016; Block et al., 2018b; Polzin et al., 2018). Among them, Vulkan et al. (2016) compared ECF and reward crowdfunding, while Lukkarinen et al. (2017) suggested that the crowd does not adopt the same investment decision criteria used by $\mathrm{VCs}$ or BAs. This latter study also showed that ECF performance is related to pre-selected crowdfunding campaign characteristics and the utilisation of private and public networks selected by entrepreneurs.

The choice of campaign characteristics is a typical behaviour of entrepreneurs, and it plays a key role in increasing the probability of a successful ECF campaign (Vismara, 2016). In particular, entrepreneurs decide how much information about their business communicates and the media to adopt in order to satisfy the crowd's needs and attract them to the campaign. These choices are fundamental for entrepreneurs to communicate the quality of their business to investors and provide them with credible signals (Ahlers et al., 2015; Vismara, 2016). Choosing the right campaign characteristics helps to mitigate information asymmetries, and it improves investors' knowledge of the business and their willingness to invest in it (Ahlers et al., 2015). Accordingly, we have defined our fourth hypothesis as follows:

H4. The campaign characteristics chosen by the entrepreneur affect the ECF performance.

In this study, we consider both CCC and COC. The choice of the campaign characteristics is strongly related to the decision-making process of the entrepreneur (Belleflamme et al.,2014; Lukkarinen et al, 2016). Entrepreneurs, in fact, are free to decide the type of CCC and COC to disclose as he or she tries to attract investors (Belleflamme et al., 2014; Vismara, 2016).

According to Dorfleitner et al. (2018, p. 524), CCCs are typically "entrepreneurial behaviours in crowdfunding campaigns" and "this strategic communication behaviour can help investors to optimise their investment decisions".

The success of campaigns depends significantly on how the campaign is run and on the decisions of the entrepreneurs (Lukkarinen et al., 2016, p. 36). Entrepreneurs decide to send specific types of information or signals (Herbig, 1996) to investors and decide what they want to reveal to them (Belleflamme et al., 2014; Ahlers et al., 2015; Vismara, 2016). In this vein, entrepreneurs should strategically decide the factors he or she discloses within the campaigns, i.e. CCC and COC. The behaviour of decision-makers plays a key role in the online context of crowdfunding platforms (Koch and Siering, 2019). Entrepreneurs' decision-making behaviour is a highly relevant driver of ECF campaigns, able to affect their performance.

The first category, i.e. CCC, is focused on presenting the business and its products/ services, as well as on the presenting the entrepreneurs. Entrepreneurs may leverage several 
tools for CCC, such as social networks (e.g. Facebook and LinkedIn), images and updates, to influence investors (Mollick, 2014; Chan and Park, 2015; Block et al., 2018b).

The choice of CCCs is an entrepreneurial decision on the type and number of images or updates to post on online campaigns, as well as the type of social networks to leverage, such as LinkedIn, Facebook and so on. The choice of these parameters represents a specific development strategy. Social networks are strategic tools for crowd engagement (Sashi, 2012), and entrepreneurs have to manage several social networks in order to tap into a wide range of people (Keegan and Rowley, 2017). They are well-known elements that help entrepreneurs to spread information (Mollick, 2014; Colombo, 2015), overcome information asymmetries and obtain superior performance in ECF (Vismara, 2016). In fact, prior studies have highlighted that entrepreneurs' connections on social networks are positively related to funding collected and investors attracted.

In crowdfunding, updates are a way to let entrepreneurs disclose specific types of information during the campaign. Dorfleitner et al. (2018, p. 523) argued that entrepreneurs "can voluntarily communicate with their investors by posting updates" and "entrepreneurs use voluntary disclosure strategically". Entrepreneurs strategically engage in updates in order to inform the crowd about new business developments. Updates are an added value for investors, and they positively influence crowd participation. Mollick (2014) found that the number of updates and their timing are a proxy of campaign success.

Entrepreneurs also determine the type and the number of images to include in their initiatives or business plans to display their perspective on their products and/or services (Chan and Park, 2015). Images are useful in attracting investors and influence people's cognition and online behaviour. In fact, accessible and relevant images (e.g. products, business activities or prototypes) affect investment screening decisions and increase favourable judgments.

The second category, i.e. COC, includes both the equity offered and funding targets pre-determined by entrepreneurs. They choose the amount of equity offered, i.e. how much equity shares they intend to sell (Ahlers et al., 2015; Vismara, 2016), and the campaign's goal, i.e. how much funds they aim to raise (Lukkarinen et al., 2016; Vulkan et al., 2016). These specific parameters level is part of the entrepreneurs' strategic decision-making process and they may influence the business strategy (Francioni et al., 2015). Entrepreneurs decide if and how much to invest in their initiatives through equity retention (Leland and Pyle, 1977; Ahlers et al., 2015; Vismara, 2016). The amount of equity offered is related to their decision about the control and ownership of their companies (Macht and Weatherston, 2014). Prior studies (Ahlers et al., 2015; Vismara, 2016, 2018; Vulkan et al., 2016) have shown that a good indicator of entrepreneur's degree of commitment is the equity offered. These studies showed negative impacts of the amount of equity offered on ECF performance (Ahlers et al., 2015; Vismara, 2016, 2018; Vulkan et al., 2016), as it is usually seen as a negative signal as it highlights a lower commitment by entrepreneurs (Vismara, 2016), that they are less optimistic and are not confident about their company's capability to generate positive cash flow (Ahlers et al., 2015; Vismara, 2016). Contrariwise, equity retention is a positive signal of entrepreneurs' commitment (Leland and Pyle, 1977). As Vismara (2016, p. 583) argued, entrepreneurs signal their commitment through high ownership retention, thus "potential investors will perceive this behaviour as a quality signal."

Entrepreneurs who engage in ECF also decide the funding target in online campaigns and indicate a specific amount to collect. They, in fact, set a goal for minimum target funding (Lukkarinen et al., 2016) that is related to their funding needs and their strategic decisions about their company's development.

The funding target is another indicator defined by the entrepreneur (Lukkarinen et al., 2016; Vulkan et al., 2016); the higher it gets the more difficult it is for the campaign to be

\section{Exploring entrepreneurial characteristics in ECF}

1003 
$\mathrm{MD}$

59,5

1004
Figure 1.

Proposed model linking entrepreneurs characteristics, motivations, and their behaviour in the ECF campaign to ECF performance successful. A higher funding target is negatively related to a campaign's success (Mollick, 2014; Zheng et al., 2014); in fact, it represents a limit for several projects aiming for a high target and having more difficulties collecting the needed funding. This is an even more relevant constraint on platforms operating with the AON (all or nothing) model, like most ECF ones, where companies do not keep any of the pledged funds if they do not meet their funding goal.

In line with prior studies, we expected to find a positive relationship between CCC and ECF performance since a higher number of updates, images and social connections should predict the success of campaigns.

Contrariwise - consistent with previous studies - pre-selected COC should negatively affect ECF performance since both a larger percentage of equity offered by entrepreneurs and a higher funding target will reduce the likelihood of a campaign's success. Hence, the literature leads to our fourth hypotheses, as follows:

H4a. CCC has a positive effect on ECF performance.

H4b. COC has a negative effect on ECF performance.

The following Figure 1 reports the final structure of the presented hypotheses with the constructs and the hypotheses.

\section{Research method \\ Context}

This study focuses on ECF in Italy, the first country in Europe to define a specific regulation for ECF (Decreto Legge n. 179/2012 or Decreto Crescita Bis); moreover, Consob (Commissione Nazionale per le Società e la Borsa) created a national registry for ECF operators (Vismara, 2016; Rossi and Vismara, 2018). The Italian ECF market is rapidly growing, in terms of collected funding (more than 82.3 million euros (as of June 2019, 30 ${ }^{\text {th }}$ ), campaigns launched (over 400) and their success rate (about 55\%) (Politecnico di Milano, 2019). The Italian context is a vibrant case for ECF, and its policy-makers are vigilant in improving ECF regulations (e.g. a new regulation requires entrepreneurs to sell a minimum $5 \%$ of equity to professional investors, banks or innovative start-up incubators). Several studies have focused on ECF in Italy, such as Piva and Rossi-Lamastra (2018), who examined the effects of human capital signals on entrepreneurs' success, and Feola et al. (2019), who segmented the Italian ECF investors' market to investigate differences between segments and explore the investors' drivers when selecting investment proposals. These reasons led us to focus on Italy, a growing ecosystem rich in ECF innovation.

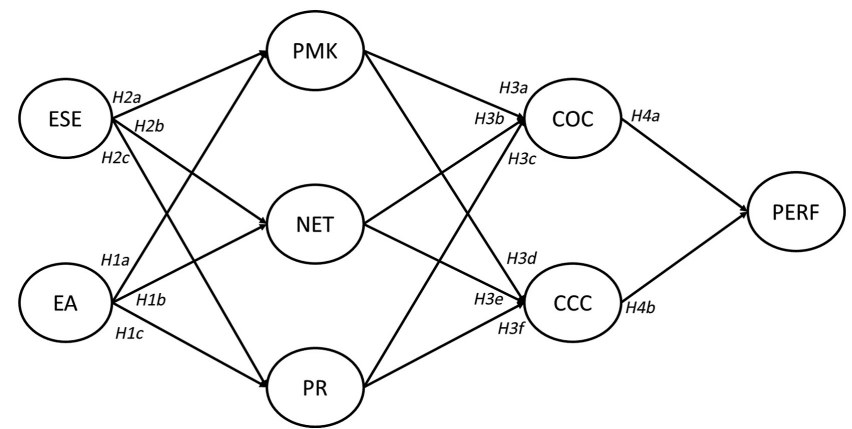


Data collection and sample

In the public national registry for ECF operators, we found 33 authorised ECF portals (Politecnico di Milano, 2019), though only 12 were eligible for this study as they were active and not specialised in real estate. We collected data on all the campaigns that ended before September 2019. The related data are shown in Table 1.

We used an online survey to collect data on entrepreneurs' EA, ESE and motivations to use ECF, using scales previously validated in the academic literature. A pilot version of the survey was administered to a small number of ECF entrepreneurs to collect their feedback on each single measure, the questions' wording and their familiarity with the survey topics (Podsakoff et al., 2012). This feedback drove us to group the motivations into three main dimensions: PMK, NET and PR.

We administered the survey using both emails and LinkedIn, and the data collection lasted eight weeks, from July to September, with two reminders sent to increase the number of participants.

In total, we surveyed 368 companies on the 12 valid ECF platforms; the questionnaire was answered by 122 entrepreneurs (33.15\% answer rate), but we had to delete 25 questionnaires as they were incomplete. Thus, we had a final sample size of 97 companies $(26.36 \%$ of the companies - 97 out of 368). The survey sample included both successful (81\%) and failed projects $(19 \%)$ ). About $77 \%$ of companies were start-ups and $23 \%$ were small- and mediumsized enterprises (SMEs), while about 65\% belonged to the service industry. We made a data check through official business register databases (e.g. Register of Innovative Start-ups/ SMEs) and the major search engine and start-up information sites (crunchbase, AngelList etc.) to better identify the type (whether a start-up or an SME) and sector (according to the Ateco classification) of each company.

The data on each campaign characteristic and ECF performance were hand-collected. In particular, we collected information about the COC (such as the amount of equity offered and target capital), the CCC (such as updates, images or links to their social network profiles) and the ECF outcomes (such as success of fundraising, the final percentage of funding collected, the number of final investors involved and the final capital collected, in euros).

To check for potential non-response bias, we conducted a wave analysis (Zollo et al., 2017, 2019) comparing the respondents in the three periods on several variables relevant in the literature and on the following performance variables: start-up status and type of company (service or not). The $t$-tests found no statistically significant differences between the three groups; for example, for the type of company (i.e. the proportion of service companies in the group) the $p$-value between the first and the second wave was 0.58 , between the first and the
Exploring entrepreneurial characteristics in $\mathrm{ECF}$

1005

\begin{tabular}{|c|c|c|c|c|}
\hline ECF platform & Date of authorisation & No. Campaigns & $\%$ In sample & \\
\hline 200crowd (formerly TIP Ventures) & 06/18/2014 & 35 & $34.3 \%$ & \\
\hline Action Crowd (formerly Assitecacrowd) & 02/06/2014 & 5 & $20 \%$ & \\
\hline BackToWork24 (formerly Equinvest) & 01/14/2015 & 39 & $43.6 \%$ & \\
\hline CrowdFundMe & 07/30/2014 & 79 & $30.4 \%$ & \\
\hline Fundera & 09/10/2014 & 1 & $100 \%$ & \\
\hline In-vestire & 01/28/2015 & 2 & $50 \%$ & \\
\hline Mamacrowd & 08/06/2014 & 71 & $21.1 \%$ & \\
\hline MuumLab & 08/06/2014 & 6 & $33.3 \%$ & \\
\hline NextEquity & 07/16/2014 & 10 & $20 \%$ & \\
\hline Opstart & 11/11/2015 & 51 & $17.7 \%$ & Table 1. \\
\hline StarsUp & 10/18/2013 & 43 & $18.6 \%$ & ECF platforms and \\
\hline WeAreStarting & $12 / 16 / 2014$ & 26 & $19.2 \%$ & campaigns \\
\hline
\end{tabular}


third wave it was 0.54 and between the first and the second it was 0.95 . Accordingly, the nonrespondent bias was not an issue in our data sampling.

\section{Measures}

In order to measure EA and ESE, we used the scales previously validated by Tang et al. (2012) and Zhao et al. (2005), respectively. The EA scale is divided into three dimensions for a total of 13 items (six for scanning and searching for information (SS), three for association and connection (AC) and four for evaluation and judgement (EJ)) (Tang et al., 2012). According to Tang et al. (2012), SS improves the entrepreneurs' knowledge (Dimov and Shepherd, 2005) and offers them multiple possibilities (Kirzner, 1979); it favours their investigations (Busenitz, 1996). More extensive SS helps in enhancing alertness to business opportunities (Ericsson et al., 1993). AC has a key role in allowing entrepreneurs to move out of the routine and innovate (Gaglio and Katz, 2001). It is the dimension used to receive and process new information to make unique connections. EJ refers to the identification of profitable business opportunities and judgement of the potential of new information to match it with existing ideas or prototypes (Baron, 2006). The judgments of these opportunities and their related actions represent a central element of EA (McMullen and Shepherd, 2006). In this study we adopted this tri-partition and assumed that the three dimensions have a key role in the EDM process.

The ESE scale was developed by Zhao et al. (2005), identifying four central items (new business opportunities, creating new products, thinking creatively and commercialising an idea or new development). The entrepreneurial motivation construct, based on previous studies (Di Pietro et al., 2018; Estrin et al., 2018), evaluated the relative importance of several potential inputs as a valid motivation to use ECF. All the items were measured on a five-point Likert Scale. Because the original scales were in English, we followed standard translation and back-translation procedures to get the Italian versions (Saunders and Lewis, 2012).

In order to reduce the method biases (Podssakof et al., 2012), we collected the campaign characteristics directly from the ECF platforms instead of asking them of the entrepreneurs. We collected the number of updates (Mollick, 2014; Block et al., 2018b; Dorfleitner et al., 2018), the number of images (Chan and Park, 2015; Bretschneider and Leimeister, 2017) and the entrepreneurs' social networks presence (Mollick, 2014; Vismara, 2016), as indicators related to $\mathrm{CCC}$. We also measured COC using the equity offered in percentage and the target amount of funding (Ahlers et al., 2015; Lukkarinen et al., 2016; Vismara, 2016, 2018; Vulkan et al., 2016).

Finally, we measured ECF performance using three commonly used proxies: the final percentage of funding collected, the final number of investors and the total funds collected (Ahlers et al., 2015; Lukkarinen et al., 2016; Vismara, 2016, 2018). The final percentage of funding collected was a more fine-tuned measure of ECF success when the fundraising exceeded the target goal, and it may have measured its failure when the fundraising did not reach the target goal (Vismara, 2016, 2018). The final number of investors was a count variable and indicated the crowd participation in terms of numbers of investors involved at the end of a campaign (Ahlers et al., 2015; Vismara, 2016). This was an important measure of success, as the main logic to adopt the crowdfunding is to accumulate a large number of investors, a crowd (Vismara, 2016). The last variable, funds collected, indicated the total funding that was generated by a project (in thousands of euros) (Ahlers et al., 2015; Vismara, 2018). It is a common proxy of ECF success and measured the amount of capital raised at the end of a campaign.

The constructs and the related items are reported in Table 2.

\section{Data analysis}

We tested our model using PLS-SEM (Hair et al., 2011) with R-CRAN with the package plspm (Sanchez et al., 2017), for the model evaluation, and with the seminr package for the related 


\begin{tabular}{|c|c|c|c|c|}
\hline Constructs & Components & Example item & References & Explorin \\
\hline \multirow[t]{3}{*}{$\begin{array}{l}\text { Entrepreneurial } \\
\text { Alertness (EAs) }\end{array}$} & Alert scanning and search (SS) & $\begin{array}{l}\text { I am an avid } \\
\text { information seeker }\end{array}$ & \multirow[t]{3}{*}{ Tang et al. (2012) } & characteristic \\
\hline & $\begin{array}{l}\text { Alert association and connection } \\
\text { (AC) }\end{array}$ & $\begin{array}{l}\text { I am good at } \\
\text { "connecting dots" }\end{array}$ & & \\
\hline & Evaluation and judgment (EJ) & $\begin{array}{l}\text { I have a gut feeling } \\
\text { for potential } \\
\text { opportunities }\end{array}$ & & 1007 \\
\hline $\begin{array}{l}\text { Entrepreneurial } \\
\text { Self-Efficacy (ESE) }\end{array}$ & $\begin{array}{l}\text { Identify new business } \\
\text { opportunities, create new } \\
\text { products, thinking creatively, } \\
\text { and commercialising an idea or } \\
\text { new development }\end{array}$ & $\begin{array}{l}\text { I'm confident I'm } \\
\text { successful at } \\
\text { creating new } \\
\text { products }\end{array}$ & Zhao et al. (2005) & \\
\hline \multirow[t]{3}{*}{$\begin{array}{l}\text { Entrepreneurial } \\
\text { Motivations }\end{array}$} & Market knowledge (PMK) & $\begin{array}{l}\text { In ECF I look for } \\
\text { getting market } \\
\text { trends insights }\end{array}$ & Di Pietro et al. (2018) & \\
\hline & Networking (NET) & $\begin{array}{l}\text { In ECF I look for } \\
\text { connections with } \\
\text { key industry players }\end{array}$ & & \\
\hline & Promotion (PR) & $\begin{array}{l}\text { In ECF I look for } \\
\text { backers acting as } \\
\text { marketing channels }\end{array}$ & & \\
\hline \multirow[t]{2}{*}{$\begin{array}{l}\text { Campaigns } \\
\text { Characteristics }\end{array}$} & \multirow{5}{*}{$\begin{array}{l}\text { Campaigns' communication } \\
\text { characteristics (CCCs) } \\
\text { Campaigns' offerings } \\
\text { characteristics (COC) }\end{array}$} & \# of Images posted & $\begin{array}{l}\text { Mollick (2014); Ahlers et al. } \\
\text { (2015); Vismara (2016, }\end{array}$ & \\
\hline & & $\%$ of equity offered & $\begin{array}{l}\text { 2018); Lukkarinen et al. } \\
\text { (2016); Vulkan et al. (2016) }\end{array}$ & \\
\hline \multirow[t]{3}{*}{ ECF Performance } & & $\%$ funding collected & Ahlers et al. (2015); & \\
\hline & & $\begin{array}{l}\text { Funds collected } \\
\text { (in thousand } € \text { ) }\end{array}$ & $\begin{array}{l}\text { Lukkarinen et al. (2016); } \\
\text { Vismara (2016, 2018); }\end{array}$ & \\
\hline & & \# investors & Vulkan et al. (2016) & Constructs and items \\
\hline
\end{tabular}

tests (Ray et al., 2019). PLS-SEM has already been used in several studies on strategic management (Hulland, 1999; Sarkar et al., 2001), entrepreneurial orientation (Shehu and Mahmood, 2014; Pratono and Mahmood, 2015), digital platforms (Cenamor et al., 2019) and, more specifically, crowdfunding (He et al., 2016; Zheng et al., 2017; Sahaym et al., 2019).

The choice to adopt this particular approach to SEM, instead of the traditional covariancebased one, was also supported by several theoretical motivations. Our study is among the first to study how entrepreneurs' characteristics and behaviour is linked to campaigns' characteristics and success, so its purpose is mostly exploratory (Hair et al., 2014); moreover, our focus was on the relationship between the constructs, not on the best model to represent a given reality (Hair et al., 2011). Finally, in our case the PLS-SEM approach was the suggested approach as it did not rely on any distributional assumption of the measured variables (Henseler et al., 2009; Reinartz et al., 2009).

The model was tested for common method bias (CMB) with the full-collinearity approach (Kock and Lynn, 2012; Kock, 2015). According to this method, there is no significant risk of $\mathrm{CMB}$ if the latent VIFs are lower than the suggested limit of 3.3. In our case we found no latent VIF higher than the suggested limit, and the highest value was 2.05 for the NET construct; it followed that $\mathrm{CMB}$ was unlikely to be a significant threat in our case.

At the same time, the evaluation of PLS-SEM did not rely on any distributional assumption of the variables, and it did not evaluate a global fit measure to assess the model validity; so several authors (Chin, 1998; Henseler et al., 2009; Hair et al., 2016; Ravand and Baghaei, 2016) hold the need to study the data using a two-step approach: (1) quality of the 
outer (measurement) model and (2) assessment of the inner (structural) model predictive power.

\section{Measurement model}

The assessment of the measurement model for reflective indicators in PLS was done by looking at four indicators:

(1) Indicator reliability - Items' factor loading on their latent higher than 0.6 (Chin, 1998; Henseler et al., 2009).

(2) Construct reliability - Constructs' Dillon-Goldstein's rho (Chin, 1998) higher than 0.7; for each construct, the first Eigenvector is higher than 1 and the second Eigenvector is lower than 1 (Tenenhaus et al., 2005).

(3) Convergent validity - Average variance extracted (AVE) (Hair et al., 2016) higher than 0.50 .

(4) Discriminant validity - Items factor loading on their latent variable higher than the cross-loadings on the other constructs (Ravand and Baghaei, 2016).

In our case some items had a factor loading lower than 0.6 (namely SS1, SS3, SS4, ESE4, NET2, PR3 and Y3) and, given the exploratory nature of our study, we decided to delete them and re-run the test (Hulland, 1999; Hair et al., 2016). As shown in Tables 3 and 4, this second run passed the four tests.

\section{Hypotheses testing}

To assess the quality of the structural model, we looked (Hair et al., 2016) at the structural path coefficients defined with a bootstrap with 5,000 resamples and confirmed the related predicting power of the constructs using $R^{2}$. The related data are reported in Table 5 and Figure 2.

We found support for several of our hypotheses (namely H1b, H1c, H2a, H2b, H3a, H3e, $\mathrm{H} 3 \mathrm{f}, \mathrm{H} 4 \mathrm{a}$ and $\mathrm{H} 4 \mathrm{~b}$ ). We found support for $\mathrm{H} 1 \mathrm{~b}$ and $\mathrm{H} 1 \mathrm{c}$ showing that EA drives entrepreneurs to use ECF both to create a bigger network of relationships (factor loading $=0.187^{*}$ ) and to exploit these new connections in promoting their business (factor loading $=0.261^{*}$ ).

We found support for the negative relationship between ESE and both the motivation to leverage investors' feedback to improve products or strategies (factor loading $=-0.229 * *$ ) and to exploit the new relationship to widen the network the enterprise is embedded into (factor loading $=-0.253^{* *}$ ).

Looking at the direct effects of entrepreneurs' motivations on campaign characteristics, we found support for the hypotheses linking PMK to COC (factor loading $=-0.176^{*}$ ) and PR to CCC (factor loading $=0.307^{*}$ ), while NET had a significantly negative impact on CCC (factor loading $=-0.348 * *$ ), though we expected to find a positive one.

Finally, looking at the impact of campaigns' characteristics on ECF performance, we found a negative impact of COC on ECF performance (factor loading $=-0.210^{* *}$ ) and a positive one for CCC (factor loading $=0.484^{* * *}$ ), which confirms the related literature.

At the same time, we have found our model only had a limited predicting power for the different campaign characteristics (the $R^{2}$ of all these variables was lower than 0.1 ), but it showed a moderate predicting power for the campaign performance ( $R^{2}$ of PERF is 0.32 ).

\section{Discussion}

EDM processes in the ECF field are still largely unexplored, and the perspective of entrepreneurs is still not fully understood (Mochkabadi and Volkmann, 2018). In this paper, 


\begin{tabular}{|c|c|c|c|c|c|c|c|}
\hline Construct & Item & Loading & DG.rho & eig.1st & eig.2nd & AVE & Exploring \\
\hline \multirow[t]{3}{*}{ SS } & SS2 & 0.68 & \multirow[t]{3}{*}{0.80} & \multirow[t]{3}{*}{1.79} & \multirow[t]{3}{*}{0.95} & \multirow[t]{3}{*}{0.57} & characteristics \\
\hline & SS5 & 0.71 & & & & & in $\mathrm{FCF}$ \\
\hline & SS6 & 0.87 & & & & & \\
\hline \multirow[t]{3}{*}{$\mathrm{AC}$} & $\mathrm{ACl}$ & 0.76 & \multirow[t]{3}{*}{0.85} & \multirow[t]{3}{*}{1.94} & \multirow[t]{3}{*}{0.66} & \multirow[t]{3}{*}{0.63} & \\
\hline & $\mathrm{AC} 2$ & 0.83 & & & & & \\
\hline & $\mathrm{AC} 3$ & 0.80 & & & & & 1009 \\
\hline \multirow[t]{4}{*}{ EJ } & EJ1 & 0.83 & \multirow[t]{4}{*}{0.87} & \multirow[t]{4}{*}{2.52} & \multirow[t]{4}{*}{0.79} & \multirow[t]{4}{*}{0.63} & \\
\hline & EJ2 & 0.83 & & & & & \\
\hline & EJ3 & 0.82 & & & & & \\
\hline & EJ4 & 0.70 & & & & & \\
\hline \multirow[t]{3}{*}{ ESE } & ESE1 & 0.75 & \multirow[t]{3}{*}{0.86} & \multirow[t]{3}{*}{2.04} & \multirow[t]{3}{*}{0.54} & \multirow[t]{3}{*}{0.68} & \\
\hline & ESE2 & 0.83 & & & & & \\
\hline & ESE3 & 0.88 & & & & & \\
\hline \multirow[t]{5}{*}{ PMK } & PMK1 & 0.72 & \multirow[t]{5}{*}{0.89} & \multirow[t]{5}{*}{3.03} & \multirow[t]{5}{*}{0.69} & \multirow[t]{5}{*}{0.60} & \\
\hline & PMK2 & 0.83 & & & & & \\
\hline & PMK3 & 0.74 & & & & & \\
\hline & PMK4 & 0.81 & & & & & \\
\hline & PMK5 & 0.80 & & & & & \\
\hline \multirow[t]{3}{*}{ NET } & NET1 & 0.76 & \multirow[t]{3}{*}{0.85} & \multirow[t]{3}{*}{1.95} & \multirow[t]{3}{*}{0.65} & \multirow[t]{3}{*}{0.63} & \\
\hline & NET3 & 0.93 & & & & & \\
\hline & NET4 & 0.69 & & & & & \\
\hline PR & PR1 & 0.82 & 0.87 & 1.52 & 0.48 & 0.76 & \\
\hline & PR2 & 0.92 & & & & & \\
\hline $\mathrm{COC}$ & $\mathrm{COC} 1$ & 0.86 & 0.83 & 1.43 & 0.57 & 0.72 & \\
\hline & $\mathrm{COC} 2$ & 0.87 & & & & & \\
\hline $\mathrm{CCC}$ & $\mathrm{CCC1}$ & 0.88 & 0.79 & 1.31 & 0.69 & 0.65 & \\
\hline & $\mathrm{CCC} 2$ & 0.73 & & & & & \\
\hline PERF & Y1 & 0.94 & 0.93 & 1.74 & 0.26 & 0.87 & \\
\hline & $\mathrm{Y} 2$ & 0.93 & & & & & Validity and reliability \\
\hline Note(s): *1 & were con & after deleti & cators wit & adings & & & evidence \\
\hline
\end{tabular}

we looked into EDM to improve the current knowledge on this topic, and we have tried to shed some light on the importance of entrepreneurial characteristics, motivations and behaviours in this field. This paper contributes to the current literature on EDM and ECF.

Recently, there has been increasing interest in understanding ECF as both its volume and the number of entrepreneurs who use it are growing exponentially (Massolution, 2016; Technavio, 2018; Politecnico di Milano, 2019). Existing studies have enhanced our understanding of ECF performance and investors (Ahlers et al., 2015; Lukkarinen et al., 2016; Vismara, 2016, 2018; Vulkan et al., 2016; Block et al., 2018b; Polzin et al., 2018; Feola et al., 2019), yet the research on entrepreneurs is at its infancy; further research has been suggested to develop a solid understanding about EDM in this specific context and how entrepreneurs use this new system.

\section{Theoretical implications}

Our study focused on entrepreneurs and, therefore, we looked at entrepreneurial characteristics underlying EDM. We distinguished two well-known types of entrepreneurial characteristics, EA and ESE. Then we focused on entrepreneurial motivations in terms of PMK, PR and NET. Finally, we looked at two classes of campaign characteristics (COC and CCC).

Our findings highlight that both entrepreneurial characteristics have a significant impact on motivations in adopting ECF. EA positively influences both NET and PR, confirming, at 


\begin{tabular}{|c|c|c|c|c|c|c|c|c|c|c|c|c|}
\hline \multirow{6}{*}{$\begin{array}{l}\mathrm{MD} \\
59,5\end{array}$} & & & & & & & & & & & & \\
\hline & Item & Construct & SS & $\mathrm{AC}$ & EJ & ESE & PMK & NET & PR & $\mathrm{COC}$ & $\mathrm{CCC}$ & PERF \\
\hline & SS2 & SS & 0.68 & 0.30 & 0.44 & 0.12 & -0.07 & 0.01 & 0.04 & 0.06 & 0.03 & 0.02 \\
\hline & SS5 & SS & 0.71 & 0.17 & 0.07 & -0.28 & 0.16 & 0.28 & 0.18 & -0.05 & -0.13 & 0.11 \\
\hline & SS6 & SS & 0.87 & 0.20 & 0.19 & -0.18 & 0.09 & 0.14 & 0.10 & 0.01 & -0.09 & 0.06 \\
\hline & $\mathrm{AC} 1$ & $\mathrm{AC}$ & 0.15 & 0.76 & 0.21 & 0.19 & -0.07 & -0.15 & -0.11 & -0.05 & 0.02 & 0.13 \\
\hline \multirow{25}{*}{1010} & $\mathrm{AC} 2$ & $\mathrm{AC}$ & 0.36 & 0.83 & 0.58 & 0.11 & 0.10 & 0.06 & 0.15 & -0.22 & 0.13 & 0.19 \\
\hline & AC3 & $\mathrm{AC}$ & 0.16 & 0.80 & 0.36 & 0.18 & 0.07 & 0.07 & 0.04 & -0.15 & -0.01 & 0.15 \\
\hline & EJ1 & EJ & 0.27 & 0.49 & 0.83 & 0.15 & 0.07 & 0.06 & 0.08 & -0.05 & -0.12 & 0.12 \\
\hline & EJ2 & EJ & 0.33 & 0.36 & 0.83 & 0.07 & 0.10 & 0.08 & 0.29 & 0.02 & -0.07 & 0.21 \\
\hline & EJ3 & EJ & 0.33 & 0.32 & 0.82 & 0.02 & 0.12 & 0.15 & 0.33 & -0.07 & -0.04 & 0.21 \\
\hline & EJ4 & EJ & 0.11 & 0.52 & 0.70 & 0.18 & -0.05 & -0.05 & 0.03 & -0.14 & 0.18 & 0.23 \\
\hline & ESE1 & ESE & -0.03 & 0.16 & 0.08 & 0.75 & -0.16 & -0.16 & -0.04 & 0.14 & 0.03 & -0.10 \\
\hline & ESE2 & ESE & -0.08 & 0.15 & 0.19 & 0.83 & -0.17 & -0.17 & -0.06 & -0.04 & -0.08 & 0.02 \\
\hline & ESE3 & ESE & -0.16 & 0.16 & 0.06 & 0.88 & -0.17 & -0.23 & -0.15 & 0.12 & -0.14 & -0.12 \\
\hline & PMK1 & PMK & -0.04 & 0.09 & 0.17 & -0.07 & 0.72 & 0.49 & 0.32 & -0.12 & -0.04 & 0.07 \\
\hline & PMK2 & PMK & 0.16 & 0.09 & 0.19 & -0.11 & 0.83 & 0.38 & 0.47 & -0.19 & 0.05 & 0.07 \\
\hline & PMK3 & PMK & 0.02 & 0.07 & -0.02 & -0.18 & 0.74 & 0.50 & 0.43 & -0.19 & 0.00 & -0.05 \\
\hline & PMK4 & PMK & 0.05 & -0.03 & -0.05 & -0.25 & 0.81 & 0.56 & 0.48 & -0.14 & 0.06 & 0.00 \\
\hline & PMK5 & PMK & -0.02 & 0.02 & 0.03 & -0.17 & 0.80 & 0.48 & 0.42 & -0.18 & 0.03 & 0.00 \\
\hline & NET1 & NET & 0.06 & -0.06 & 0.06 & -0.15 & 0.53 & 0.76 & 0.62 & -0.13 & 0.04 & 0.02 \\
\hline & NET3 & NET & 0.15 & 0.02 & 0.07 & -0.24 & 0.50 & 0.93 & 0.53 & -0.18 & -0.14 & 0.00 \\
\hline & NET4 & NET & 0.20 & 0.06 & 0.06 & -0.12 & 0.48 & 0.69 & 0.48 & 0.02 & -0.07 & 0.04 \\
\hline & PR1 & PA & 0.15 & 0.03 & 0.25 & -0.06 & 0.46 & 0.52 & 0.82 & -0.06 & 0.12 & 0.13 \\
\hline & PR2 & PA & 0.10 & 0.07 & 0.18 & -0.13 & 0.50 & 0.60 & 0.92 & -0.22 & 0.13 & 0.25 \\
\hline & $\mathrm{COC} 1$ & $\mathrm{COC}$ & -0.02 & -0.21 & -0.03 & 0.01 & -0.22 & -0.14 & -0.16 & 0.86 & -0.11 & -0.18 \\
\hline & COC2 & $\mathrm{COC}$ & 0.05 & -0.12 & -0.08 & 0.14 & -0.15 & -0.11 & -0.14 & 0.87 & -0.28 & -0.36 \\
\hline & $\mathrm{CCC1}$ & $\mathrm{CCC}$ & 0.02 & 0.05 & -0.02 & -0.15 & 0.05 & -0.09 & 0.18 & -0.16 & 0.88 & 0.44 \\
\hline & CCC2 & $\mathrm{CCC}$ & -0.19 & 0.07 & -0.03 & 0.04 & -0.01 & -0.07 & 0.02 & -0.23 & 0.73 & 0.42 \\
\hline & Y1 & PERF & 0.03 & 0.18 & 0.19 & -0.01 & 0.06 & 0.03 & 0.26 & -0.33 & 0.48 & 0.94 \\
\hline & Y2 & PERF & 0.12 & 0.21 & 0.25 & -0.16 & -0.01 & -0.01 & 0.18 & -0.28 & 0.51 & 0.93 \\
\hline
\end{tabular}

Table 4. Note(s): Legend: Values in italics Item factor loading on their latent; Values in roman: Item cross-loading on the Discriminant validity construct in the column's heading

least in part, some previous studies (e.g. Vismara, 2016; Di Pietro et al., 2018). This agrees with some scholars (Gaglio and Katz, 2001; Tang et al., 2012) who hold that EA allows entrepreneurs to identify new opportunities (Gaglio and Winter, 2017a; Roundy et al., 2018; Patel, 2019), which leads them to leverage the crowd to improve their networking capabilities (Ebbers, 2014; Adomako et al., 2018). This is done not only to get access to more networks but also to engage the crowd in promoting their business, further helping them gain access to new relationships. Our model supports the idea that EA allows entrepreneurs to be more sensitive and vigilant to the environment and drives them to interact with other players to discover new opportunities (Ardichvili et al., 2003).

Our data support the idea that ESE, however, reduces the perceived need for external inputs, not only for their products or the markets they are targeting (as expected from several studies) (Zhao et al., 2005; Drnovšek et al., 2010) but also for their networking capabilities. This highlights the idea that the more entrepreneurs are focused on their capabilities the less they will look for talent from the outside.

Moreover, our study suggests that both the entrepreneurial characteristics we have considered are needed to explain the three classes of entrepreneurial motivations, even if the low $R^{2}$ highlights the need to study these topics more.

Our results show that an entrepreneur's motivation can have a meaningful impact on the characteristics the entrepreneur chooses for their ECF campaign. As expected, when the entrepreneur starts a campaign to get new information or feedback on their products and/or 


\begin{tabular}{|c|c|c|c|c|c|c|c|c|}
\hline \multicolumn{2}{|c|}{ Hypotheses } & $\begin{array}{l}\text { Path } \\
\text { coeff }\end{array}$ & $\begin{array}{l}\text { Boot } \\
\text { std. Err. }\end{array}$ & $\begin{array}{c}\text { Perc. } \\
0.5\end{array}$ & $\begin{array}{l}\text { Perc. } \\
0.95\end{array}$ & $t$-value & Support & \multirow{2}{*}{$\begin{array}{r}\text { Exploring } \\
\text { entrepreneurial } \\
\text { characteristics } \\
\text { in ECF }\end{array}$} \\
\hline H1 & $\begin{array}{l}\text { Entrepreneurial Alertness on } \\
\text { Motivations }\end{array}$ & & & & & & & \\
\hline H1a & $\begin{array}{l}\text { Entrepreneurial Alertness on } \\
\text { Product and Market Knowledge }\end{array}$ & 0.162 & 0.115 & -0.027 & 0.351 & 1.412 & NS & \\
\hline $\mathrm{H} 1 \mathrm{~b}$ & $\begin{array}{l}\text { Entrepreneurial Alertness on } \\
\text { Networking }\end{array}$ & 0.187 & 0.109 & 0.007 & 0.367 & 1.711 & Yes* & 1011 \\
\hline $\mathrm{H} 1 \mathrm{c}$ & $\begin{array}{l}\text { Entrepreneurial Alertness on } \\
\text { Promotion }\end{array}$ & 0.261 & 0.097 & 0.101 & 0.421 & 2.690 & Yes* & \\
\hline $\mathrm{H} 2$ & $\begin{array}{l}\text { Entrepreneurial Self-Efficacy on } \\
\text { Motivations }\end{array}$ & & & & & & & \\
\hline $\mathrm{H} 2 \mathrm{a}$ & $\begin{array}{l}\text { Entrepreneurial Self-Efficacy on } \\
\text { Product and Market Knowledge }\end{array}$ & -0.229 & 0.106 & -0.404 & -0.055 & -2.166 & Yes** & \\
\hline $\mathrm{H} 2 \mathrm{~b}$ & $\begin{array}{l}\text { Entrepreneurial Self-Efficacy on } \\
\text { Networking }\end{array}$ & -0.253 & 0.086 & -0.395 & -0.111 & -2.937 & Yes** & \\
\hline $\mathrm{H} 2 \mathrm{c}$ & $\begin{array}{l}\text { Entrepreneurial Self-Efficacy on } \\
\text { Promotion }\end{array}$ & -0.127 & 0.097 & -0.286 & 0.032 & -1.318 & NS & \\
\hline H3 & $\begin{array}{l}\text { Motivations on Campaign } \\
\text { Characteristics }\end{array}$ & & & & & & & \\
\hline H3a & $\begin{array}{l}\text { Product and Market Knowledge on } \\
\text { Campaign Offer }\end{array}$ & -0.176 & 0.101 & -0.342 & -0.011 & -1.750 & Yes* & \\
\hline $\mathrm{H} 3 \mathrm{~b}$ & $\begin{array}{l}\text { Product and Market Knowledge on } \\
\text { Campaign Presentation }\end{array}$ & 0.058 & 0.150 & -0.188 & 0.304 & 0.389 & NS & \\
\hline $\mathrm{H} 3 \mathrm{c}$ & Networking on Campaign Offer & 0.053 & 0.147 & -0.188 & 0.294 & 0.361 & NS & \\
\hline H3d & $\begin{array}{l}\text { Networking on Campaign } \\
\text { Communication }\end{array}$ & -0.348 & 0.153 & -0.600 & -0.096 & -2.272 & $\mathrm{NO}^{* * *}$ & \\
\hline H3e & Promotion on Campaign Offer & -0.110 & 0.157 & -0.368 & 0.149 & -0.697 & NS & \\
\hline H3f & $\begin{array}{l}\text { Promotion on Campaign } \\
\text { Communication }\end{array}$ & 0.307 & 0.181 & 0.008 & 0.605 & 1.692 & Yes* & \\
\hline H4 & $\begin{array}{l}\text { Campaign Characteristics on ECF } \\
\text { Performance }\end{array}$ & & & & & & & \\
\hline $\mathrm{H} 4 \mathrm{a}$ & Campaign Offer on Performance & -0.210 & 0.059 & -0.308 & -0.112 & -3.534 & Yes** & \\
\hline $\mathrm{H} 4 \mathrm{~b}$ & $\begin{array}{l}\text { Campaign Communication on } \\
\text { Performance }\end{array}$ & 0.484 & 0.079 & 0.353 & 0.615 & 6.093 & Yes*** & $\begin{array}{r}\text { Table } 5 . \\
\text { Structural model }\end{array}$ \\
\hline & $\begin{array}{l}\text { s): Yes }=\text { supported; } \mathrm{NO}=\text { Not sup } \\
.1 ; * * p<0.05 ; * * * p<0.01 \text { (based on }\end{array}$ & $\begin{array}{l}\text { ted; NS } \\
, 999), \text { On }\end{array}$ & $\begin{array}{l}\text { hot signi } \\
\text { ailed tes }\end{array}$ & & & & & $\begin{array}{r}\text { results and path } \\
\text { coefficient }\end{array}$ \\
\hline
\end{tabular}

the target market, they will lower their COC (Vismara, 2016; Di Pietro et al., 2018; Estrin et al., 2018). At the same time, we found no evidence of these motivations' effects on the CCC, as was expected from the existing literature (Bretschneider and Leimeister, 2017; Block et al., 2018b).

Our analysis does not support the idea that entrepreneurs wanting to expand their network will lower some COCs (we were expecting a positive effect of these motivations on their CCC) (Brown et al., 2019). According to some authors (Belleflamme et al., 2014; Vismara, 2016), the crowd is mostly composed of amateurs with limited experience who are only useful for increasing word of mouth (Cholakova and Clarysse, 2015; Vismara, 2018). These findings agree with some scholars (Ahlers et al., 2015; Lukkarinen et al., 2016; Vismara, 2016) who hold that when entrepreneurs prefer to attract more experienced investors, they will try to leverage the funding target and equity offered as signs of their commitment.

This study's framework highlights, in support of previous findings by several authors (Mollick, 2014, Block et al., 2108b), that entrepreneurs looking to exploit ECF as a way to promote their business or their business idea will increase the CCC of their campaign (such as adding more photos or updating the campaign more often) (Wald et al., 2019). 
$\mathrm{MD}$

59,5

1012

Figure 2.

Results of the model evaluation

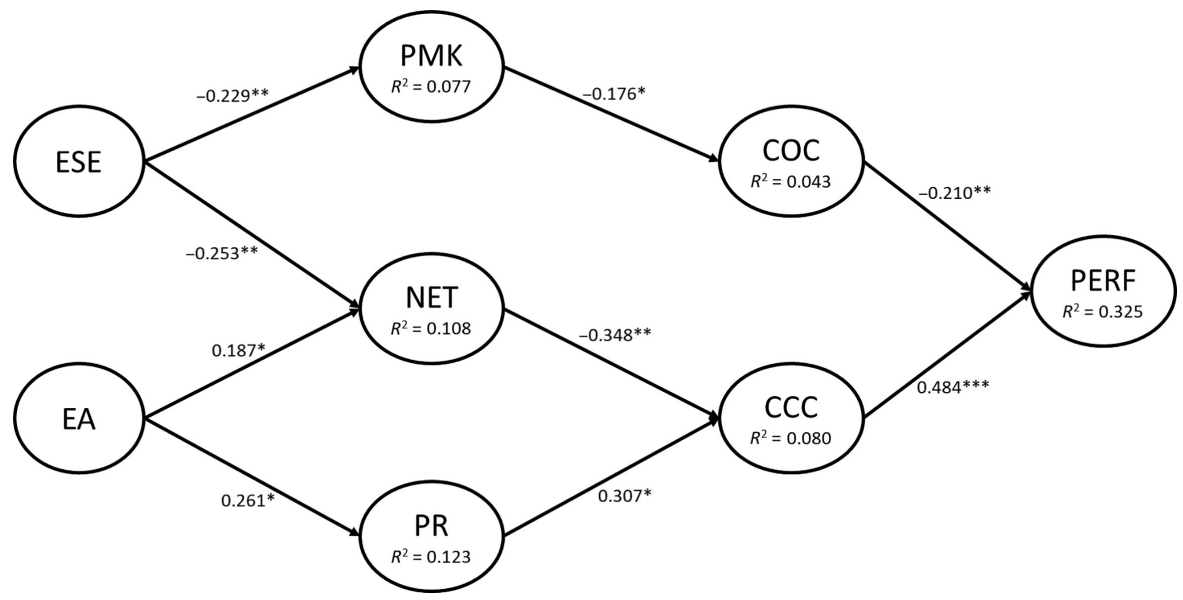

Finally, we found strong support for our last two sub-hypotheses. As suggested by prior studies (Ahlers et al., 2015; Lukkarinen et al., 2016; Vismara, 2016, 2018; Vulkan et al., 2016), campaign characteristics influence ECF performance. Specifically, CCC has a positive impact on $\mathrm{ECF}$ performance, while $\mathrm{COC}$ has a negative impact.

\section{Managerial and practical implications}

The findings of this research, highlighting some suggestions to improve EDM processes in $\mathrm{ECF}$, may also provide useful implications for entrepreneurs and policymakers.

This research warns entrepreneurs to be aware of their decision-making processes and to evaluate and monitor them over time. When entrepreneurs improve their understanding of $\mathrm{EDM}$ - a complex process in which their characteristics, motivations and behaviours are linked to each other - they will make better decisions, avoiding biases and increasing their effectiveness.

Our results might help them to more clearly define their choices in ECF campaigns and to align their campaign characteristics with the desired results they need to grow their business (Wald et al., 2019). Entrepreneurs, in fact, need to not only manage crowd inputs to get additional resources but also create added value for their companies. The results might help entrepreneurs to enhance their choices and actions to support their business development.

Entrepreneurs adopting ECF should, above all, consider the kind of backers they want to attract. When they want to attract experienced investors, they should set their campaign offer at an adequate level to attract external stakeholders and relevant industry players (Di Pietro et al., 2018). This is an intriguing insight since in the current scenario it is relevant to understanding how entrepreneurs deal with other stakeholders (Caputo et al., 2018). Moreover, our results highlight that entrepreneurs may adopt ECF as an OI platform to get meaningful feedback and as a tool to promote their business; these two motivations are significantly related to ECF performance, showing that these two objectives may reinforce each other.

However, entrepreneurs should pay attention to their self-efficacy and to the idea that ECF may provide them only with financial resources as, according to our data, this is a selfdefeating approach; it increases the focus on campaign characteristics linked to the offer, while reducing those linked to communication, effectively reducing the possibility to reach success. 
Also, investors, platform managers and authorities would find it useful to understand the EDM process in ECF as presented in this research. This research highlights that policymakers and platform managers should try to engage more sophisticated investors since entrepreneurs still do not consider ECF platforms as a viable source of valuable relationships (Di Pietro et al., 2018). Adding these new investors may prove useful in making ECF more attractive to entrepreneurs without having to lose the knowledge value of the crowd. This is particularly relevant as even if we had found a positive and statistically significant effect of CCC on ECF performance (factor loading $=0.48$ ), the NET and PR effects on CCC are opposite, potentially negating each other's beneficial effects.

Our data highlight that both the motivation to get feedback from the crowd and the one to leverage the crowd as ambassadors for the company increase ECF performance (Mollick, 2014; Vismara, 2016; Block et al., 2018b; Polzin et al., 2018); accordingly, platform managers should try to help entrepreneurs use them to more actively engage the crowd. One option could be to suggest entrepreneurs provide a minimum number of updates for their campaigns or to provide them with a forum to interact proactively with their potential backers.

EDM may be considered from the perspective of national ECF programs. Often, such programs tend to emphasise the intuitive side of decision-making, while the focus on entrepreneurs remains underestimated. For these reasons, it might be useful for academics and institutions to start looking at entrepreneurs as strategic decision-makers who need to develop and be more aware of their EDM process as well as the role of their characteristics, motivation and behaviours. Hence, authorities and policymakers should offer specific programs in which both EDM and strategic thinking are promoted for entrepreneurial success in new contexts like ECF. Authorities (e.g. Consob in Italy) are interested in the entrepreneurial dynamics of ECF and trying to encourage entrepreneurs to not only use ECF to get financial resources.

\section{Conclusions, limitations and avenues for future research}

This study is among the first focused on EDM in the ECF context. We have explored some entrepreneurial decisions that precede the launch of a campaign, and we have found that at the base of EDM there are important entrepreneurial characteristics influencing their motivations and behaviour.

Entrepreneurs that decide to use ECF present different levels of EA and ESE, leading them to search for different opportunities deriving from crowd exploitation (PMK, NET and $\mathrm{PR})$. These motivations in turn influence entrepreneurial behaviours ( $\mathrm{CCC}$ and $\mathrm{COC}$ ) and, as a consequence, ECF performance.

This study leveraged well-known constructs in the literature and developed a theoretical framework based on EDM theory to understand decisions by entrepreneurs in a new context.

The added value of this research lies in the analysis of the entrepreneurial aspects underlying entrepreneurial decisions to use ECF. Our results highlight that these aspects are central in decision-making and play a key role in the ECF context. The study highlights that the choice of campaign characteristics is only the last step of a much broader process in which both the characteristics and motivations of the entrepreneur have significant importance. Moreover, our research points to the need to study the pre-campaign phases as a way to further contribute to the EDM literature.

Our research is explorative and limited in several ways. Given the novelty of both the context and the topic, there is a scarcity of other contributions based on entrepreneurial perspectives, and, in particular, there is a lack of studies which specifically explore EDM in $\mathrm{ECF}$. This is the first, and most important, limitation of our research since we cannot make 
comparisons with previous studies in this field to find support for our results or not. We acknowledge that this was an explorative study, so we have investigated EDM in the ECF context using well-known constructs - i.e. EA and ESE - without considering other entrepreneurial motivations, traits and characteristics that could be explored to improve our understanding of EDM in ECF. The second limitation is that we focused on three types of entrepreneurial aspects, but other parameters could be examined for the same purpose. This offers several possible avenues of future research. In this vein, other intriguing aspects of EDM to investigate within the ECF context could be related to emotions, cognitive parameters, entrepreneurial capabilities and how the relationship with the surrounding environment affects entrepreneurs' judgments (Sadler-Smith, 2004; Cardon et al., 2012; Foss et al., 2019).

Another limitation of the research lies in the sample size, $26.36 \%$ of the actual Italian ECF population, but as ECF is growing in numbers and rapidly evolving, thanks to new technologies (e.g. ICOs, STOs and IEOs) (Politecnico di Milano, 2019), our data will probably need to be updated soon even if the number of entrepreneurs fully interviewed represents today a satisfactory sample, given the novelty and the dimension of ECF (different from other models, such as reward crowdfunding). In the future it will be possible to enlarge the survey sample by replicating the interviews through different sources (e.g. phone-based interviews) and enrich the data, thanks to new campaigns that have been launched since this study's inception by other entrepreneurs.

Moreover, as this is a novel topic, scholars still have to develop a full set of validated scales for these constructs that could increase these studies' predictive power; new research attempts should use more engaging methodologies in order to capture more personal characteristics, such as emotions, cognitive parameters and environments.

\section{References}

Adomako, S., Danso, A., Boso, N. and Narteh, B. (2018), "Entrepreneurial alertness and new venture performance: facilitating roles of networking capability", International Small Business Journal: Researching Entrepreneurship, Vol. 36 No. 5, pp. 453-472.

Agostini, L. and Nosella, A. (2019), "The adoption of Industry 4.0 technologies in SMEs: results of an international study", Management Decision, Vol. 58 No. 4, pp. 625-643.

Ahlers, G.K., Cumming, D., Günther, C. and Schweizer, D. (2015), "Signaling in equity crowdfunding", Entrepreneurship: Theory and Practice, Vol. 39 No. 4, pp. 955-980.

Ardichvili, A., Cardozo, R. and Ray, S. (2003), "A theory of entrepreneurial opportunity identification and development", Journal of Business Venturing, Vol. 18 No. 1, pp. 105-123.

Baeck, P., Collins, L. and Zhang, B. (2014), Understanding Alternative Finance: The UK Alternative Finance Industry Report 2014, Nesta, London.

Balodi, K. (2019), "Strategic orientations and performance of young ventures: moderating role of environmental turbulence", Management Decision, Vol. 58 No. 4, pp. 666-686.

Bandura, A. (1977), "Self-efficacy: toward a unifying theory of behavioral change", Psychological Review, Vol. 84 No. 2, pp. 191-215.

Bandura, A. (1997), Self-efficacy: The Exercise of Control, Freeman, New York.

Bandura, A. (1986), Social Foundations of Thought and Action: A Social Cognitive Theory, Prentice-Hall, Englewood Cliffs, NJ.

Barbosa, S., Gerhardt, M. and Kickul, J. (2007), "The role of cognitive style and risk preference on entrepreneurial self-efficacy and entrepreneurial intentions", Journal of Leadership and Organizational Studies, Vol. 13 No. 4, pp. 86-104.

Barney, J.B. (2001), "Resource-based theories of competitive advantage: a ten-year retrospective on the resource-based view", Journal of Management, Vol. 27 No. 6, pp. 643-650. 
Baron, R.A. (2006), "Opportunity recognition as pattern recognition: how entrepreneurs 'connect the dots' to identify new business opportunities", Academy of Management Perspectives, Vol. 20 No. 1, pp. 104-119.

Baum, J.R. and Locke, E.A. (2004), "The relationship of entrepreneurial traits, skill, and motivation to subsequent venture growth", Journal of Applied Psychology, Vol. 89 No. 4, pp. 587-598.

Bayon, M., Lafuente, E. and Vaillant, Y. (2016), "Human capital and the decision to exploit innovative opportunity", Management Decision, Vol. 54 No. 7, pp. 1615-1632.

Belleflamme, P., Lambert, T. and Schwienbacher, A. (2014), "Crowdfunding: tapping the right crowd", Journal of Business Venturing, Vol. 29 No. 5, pp. 585-609.

Block, J.H., Colombo, M.G., Cumming, D.J. and Vismara, S. (2018a), "New players in entrepreneurial finance and why are there", Small Business Economics, Vol. 50 No. 2, pp. 239-250.

Block, J.H., Hornuf, L. and Moritz, A. (2018b), "Which updates during an equity crowdfunding campaign increase crowd participation?”, Small Business Economics, Vol. 50 No. 1, pp. 3-27.

Brändle, L., Berger, E.S.C., Golla, S. and Kuckertz, A. (2018), "I am what I am - how nascent entrepreneurs' social identity affects their entrepreneurial self-efficacy", Journal of Business Venturing Insights, Vol. 9, pp. 17-23.

Bretschneider, U. and Leimeister, J.M. (2017), "Not just an Ego trip: exploring Backers' motivation for funding in incentive-based crowdfunding", The Journal of Strategic Information Systems, Vol. 26 No. 4, pp. 246-260.

Brown, R., Mawson, S. and Rowe, A. (2019), "Start-ups, entrepreneurial networks and equity crowdfunding: a processual perspective", Industrial Marketing Management, Vol. 80, pp. 115-125.

Bruton, G., Khavul, S., Siegel, D. and Wright, M. (2015), "New financial alternatives in seeding entrepreneurship: microfinance, crowdfunding, and peer-to-peer innovations", Entrepreneurship: Theory and Practice, Vol. 39 No. 1, pp. 9-26.

Bullini Orlandi, L. and Pierce, P. (2020), "Analysis or intuition? Reframing the decision-making styles debate in technological settings", Management Decision, Vol. 58 No. 1, pp. 129-145.

Busenitz, L.W. (1996), "Research on entrepreneurial alertness: sampling, measurement, and theoretical issues", Journal of Small Business Management, Vol. 34 No. 4, pp. 35-44.

Caputo, A. and Pellegrini, M. (2019), The Anatomy of Entrepreneurial Decisions Past, Present and Future Research Directions, Contributions to Management Science, Springer Nature Switzerland $\mathrm{AG}$, Cham.

Caputo, A., Marzi, G., Pellegrini, M. and Rialti, R. (2018), "Conflict management in family businesses", International Journal of Conflict Management, Vol. 29 No. 4, pp. 519-542.

Cardon, M.S., Foo, M., Shepherd, D. and Wiklund, J. (2012), "Exploring the heart: entrepreneurial emotion is a hot topic", Entrepreneurship Theory and Practice, Vol. 36 No. 1, pp. 1-10.

Cenamor, J., Parida, V. and Wincent, J. (2019), "How entrepreneurial SMEs compete through digital platforms: the roles of digital platform capability, network capability and ambidexterity", Journal of Business Research, Vol. 100, pp. 196-206.

Chan, C.S.R. and Park, H.D. (2015), "How images and color in business plans influence venture investment screening decisions", Journal of Business Venturing, Vol. 30 No. 5, pp. 732-748.

Chen, C.C., Greene, P.G. and Crick, A. (1998), "Does entrepreneurial self-efficacy distinguish entrepreneurs from managers?”, Journal of Business Venturing, Vol. 13 No. 4, pp. 295-316.

Chen, G., Gully, M.S. and Eden, D. (2004), "General self-efficacy and self-esteem: toward theoretical and empirical distinction between correlated self-evaluations", Journal of Organizational Behavior, Vol. 25 No. 3, pp. 375-395.

Chen, P.C., Chan, W.C., Hung, S.W. and Lin, D.Z. (2020), "How entrepreneurs recognise entrepreneurial opportunity and its gaps: a cognitive theory perspective", Technology Analysis and Strategic Management, Vol. 32 No. 2, pp. 223-238.

\section{entrepreneurial characteristics in $\mathrm{ECF}$}


Chesbrough, H. (2003), Open Innovation: The New Imperative for Creating and Profiting, from Technology, Harvard Business School Press, Boston, MA.

Chin, W.W. (1998), "Commentary: issues and opinion on structural equation modeling”, MIS Quarterly, Vol. 22 No. 1, pp. vii-xvi.

Cholakova, M. and Clarysse, B. (2015), "Does the possibility to make equity investments in crowdfunding projects crowd out reward-based investments?", Entrepreneurship: Theory and Practice, Vol. 39 No. 1, pp. 145-172.

Cohen, B., Amorós, J.E. and Lundy, L. (2017), "The generative potential of emerging technology to support startups and new ecosystems", Business Horizon, Vol. 60 No. 6, pp. 741-745.

Collins, L. and Pierrakis, Y. (2012), The Venture Crowd: Crowdfunding Equity Investment into Business, NESTA, London.

Colombo, M.G. (2015), "Internal social capital and the attraction of early contributions in crowdfunding", Entrepreneurship: Theory and Practice, Vol. 39 No. 1, pp. 75-100.

Politecnico di Milano (2019), Osservatori Entrepreneurship and Finance, $4^{\circ}$ Report Italiano sul CrowdInvesting, Milano, Italy.

Di Pietro, F., Prencipe, A. and Majchrzak, A. (2018), "Crowd equity investors: an underutilized asset for open innovation in startups", California Management Review, Vol. 60 No. 2, pp. 43-70.

Dimov, D.P. and Shepherd, D.A. (2005), "Human capital theory and venture capital firms: exploring 'human runs' and 'strike outs", Journal of Business Venturing, Vol. 20 No. 1, pp. 1-21.

Dorfleitner, G., Hornuf, L. and Weber, M. (2018), "Dynamics of investor communication in equity crowdfunding”, Electronic Market, Vol. 28 No. 4, pp. 523-540.

Drnovšek, M., Wincent, J. and Cardon, M. (2010), "Entrepreneurial self-efficacy and business start-up: developing a multi-dimensional definition”, International Journal of Entrepreneurial Behavior and Research, Vol. 16 No. 4, pp. 329-348.

Du, S., Yalcinkaya, G. and Bstieler, L. (2016), "Sustainability, social media driven open innovation, and new product development performance", The Journal of Product Innovation Management, Vol. 33 No. S1, pp. 55-71.

Ebbers, J.J. (2014), "Networking behavior and contracting relationships among entrepreneurs in business incubators", Entrepreneurship: Theory and Practice, Vol. 38 No. 5, pp. 1159-1181.

Ericsson, K.A., Krampe, R.T. and Tesch-Romer, C. (1993), "The role of deliberate practice in the acquisition of expert performance”, Psychological Review, Vol. 100 No. 3, pp. 363-406.

Estrin, S., Gozman, D. and Khavul, S. (2018), "The evolution and adoption of equity crowdfunding: entrepreneur and investor entry into a new market”, Small Business Economics, Vol. 51 No. 2, pp. 425-439.

Feola, R., Vesci, M., Marinato, E. and Parente, R. (2019), “Segmenting 'digital investors': evidence from the Italian equity crowdfunding market”, Small Business Economics, pp. 1-16.

Forbes (2005), "The effects of strategic decision making on entrepreneurial self-efficacy", Entrepreneurship: Theory and Practice, Vol. 29 No. 5, pp. 599-626.

Foss, N.J., Klein, P.G. and Bjørnskov, C. (2019), "The context of entrepreneurial judgment: organizations, markets, and institutions", Journal of Management Studies, Vol. 56 No. 6, pp. 1197-1213.

Francioni, B., Musso, F. and Cioppi, M. (2015), "Decision-maker characteristics and international decisions for SMEs", Management Decision, Vol. 53 No. 10, pp. 2226-2249.

Gaglio, C.M. and Katz, J.A. (2001), "The psychological basis of opportunity identification: entrepreneurial alertness", Small Business Economics, Vol. 16 No. 2, pp. 95-111.

Gaglio, C.M. and Winter, S. (2017a), "Entrepreneurial alertness and opportunity identification: where are we now?", in Brännback, M. and Carsrud, A. (Eds), Revisiting the Entrepreneurial Mind, International Studies in Entrepreneurship, Springer, Cham, Vol. 35, pp. 339-358. 
Gaglio, C.M. and Winter, S. (2017b), "Entrepreneurial alertness and opportunity identification 3.0: yes, we can talk empirical!", in Brännback, M. and Carsrud, A. (Eds), Revisiting the Entrepreneurial Mind, International Studies in Entrepreneurship, Springer, Cham, Vol. 35, pp. 359-377.

Gist, M.E. and Mitchell, T.R. (1992), "Self-efficacy: a theoretical analysis of its determinants and malleability", Academy of Management Review, Vol. 17 No. 2, pp. 183-211.

Gomezel, A. and Rangus, K. (2018), "An exploration of an entrepreneur's open innovation mindset in an emerging country", Management Decision, Vol. 56 No. 9, pp. 1869-1882.

Gormon, M. and Sahlman, W.A. (1989), "What do venture capitalists do?", Journal of Business Venturing, Vol. 4 No. 4, pp. 231-248.

Gray, C. (2006), "Absorptive capacity, knowledge management and innovation in entrepreneurial small firms", International Journal of Entrepreneurial Behavior and Research, Vol. 12 No. 6, pp. 345-360.

Günzel-Jensen, F., Moberg, K., Mauer, R. and Neergaard, H. (2017), "Self-efficacy and the entrepreneurial mindset revisited", in Brännback, M. and Carsrud, A. (Eds), Revisiting the Entrepreneurial Mind. International Studies in Entrepreneurship, Springer, Cham, Vol. 35.

Hair, J.F., Ringle, C.M. and Sarstedt, M. (2011), "PLS-SEM: indeed a silver bullet", Journal of Marketing Theory and Practice, Vol. 19 No. 2, pp. 139-52.

Hair Jr, J.F., Sarstedt, M., Hopkins, L. and Kuppelwieser, V.G. (2014), "Partial least squares structural equation modeling (PLS-SEM)", European Business Review, Vol. 26, No. 2, pp. 106-121.

Hair, J.F. Jr, Hult, G.T.M., Ringle, C. and Sarstedt, M. (2016), A Primer on Partial Least Squares Structural Equation Modeling (PLS-SEM), Sage Publications, Los Angeles.

He, W., Xu, G., Zheng, H., Hung, J.L., Qi, Z. and Xu, B. (2016), "The role of trust management in rewardbased crowdfunding", Online Information Review, Vol. 40, No. 1, pp. 97-118.

Henseler, J., Ringle, C. and Sinkovics, R. (2009), "The use of partial least squares path modeling in international marketing", in Sinkovics, R. and Ghauri, P. (Eds), New Challenges to International Marketing (Advances in International Marketing), Emerald Group Publishing Limited, Bingley, Vol. 20, pp. 277-319.

Herbig, P. (1996), "Market signalling: a review”, Management Decision, Vol. 34 No. 1, pp. 35-45.

Hitt, M.A., Ireland, R.D., Camp, S.M. and Sexton, D.L. (2001), "Strategic entrepreneurship: entrepreneurial strategies for wealth creation”, Strategic Management Journal, Vol. 22 Nos 6-7, pp. 479-491.

Hsieh, C., Huang, H. and Lee, W. (2016), "Using transaction cost economics to explain open innovation in start-ups", Management Decision, Vol. 54 No. 9, pp. 2133-2156.

Hsu, D.K., Wiklund, J. and Cotton, J.R. (2017), "Success, failure, and entrepreneurial reentry: an experimental assessment of the veracity of self-efficacy and prospect theory", Entrepreneurship: Theory and Practice, Vol. 41 No. 1, pp. 19-47.

Hulland, J. (1999), "Use of partial least squares (PLS) in strategic management research: a review of four recent studies", Strategic Management Journal, Vol. 20 No. 2, pp. 195-204.

Kahle, K.M. and Stulz, R.M. (2013), "Access to capital, investment, and the financial crisis", Journal of Financial Economics, Vol. 110 No. 2, pp. 280-299.

Kaish, S. and Gilad, B. (1991), “Characteristics of opportunities search of entrepreneurs versus executive: sources, interests, general alertness", Journal of Business Venturing, Vol. 6 No. 1, pp. 45-61.

Keegan, B. and Rowley, J. (2017), "Evaluation and decision making in social media marketing", Management Decision, Vol. 55 No. 1, pp. 15-31.

Kirzner, I.M. (1973), Competition and Entrepreneurship, University of Chicago Press, Chicago.

Kirzner, I.M. (1979), Perception, Opportunity and Profit, University of Chicago Press, Chicago.

Koch, J.A. and Siering, M. (2019), "The recipe of successful crowdfunding campaigns", Electronic Markets, Vol. 29, pp. 661-679.

\section{Exploring entrepreneurial characteristics in $\mathrm{ECF}$


Kock, N. (2015), "Common method bias in PLS-SEM: a full collinearity assessment approach", International Journal of E-Collaboration, Vol. 11 No. 4, pp. 1-10.

Kock, N. and Lynn, G. (2012), "Lateral collinearity and misleading results in variance-based SEM: an illustration and recommendations", Journal of the Association for Information Systems, Vol. 13 No. 7, pp. 546-580.

Krueger, N.J. and Brazeal, D. (1994), "Entrepreneurial potential and potential entrepreneurs", Entrepreneurship: Theory and Practice, Vol. 18 No. 3, pp. 91-104.

Kunc, M. and Bhandari, R. (2011), "Strategic development processes during economic and financial crisis", Management Decision, Vol. 49 No. 8, pp. 1343-1353.

Lambert, T. and Schwienbacher, A. (2010), "An empirical analysis of crowdfunding”, available at: http://www.crosnerlegal.com/images/47770544_An_Empirical_Analysis_of_Crowdfunding.pdf.

Leland, H.E. and Pyle, D. (1977), "Informational asymmetries, financial structure and financial intermediation", Journal of Finance, Vol. 32 No. 2, pp. 371-387.

Li, L., Su, F., Zhang, W. and Mao, J.Y. (2018), "Digital transformation by SME entrepreneurs: a capability perspective", Information Systems Journal, Vol. 28 No. 6, pp. 1129-1157.

Lindsley, D.H., Brass, D.J. and Thomas, J.B. (1995), "Efficacy-performance spirals: a multilevel perspective", Academy of Management Review, Vol. 20 No. 3, pp. 645-678.

Liu, S., Xia, F., Zhang, J. and Wang, L. (2016), "How crowdsourcing risks affect performance: an exploratory model”, Management Decision, Vol. 54 No. 9, pp. 2235-2255.

Lukkarinen, A., Teich, J.E., Wallenius, H. and Wallenius, J. (2016), "Success drivers of online equity crowdfunding campaigns", Decision Support Systems, Vol. 87 No. C, pp. 26-38.

Lumpkin, G.T. and Lichtenstein, B.B. (2005), "The role of organizational learning in the opportunityrecognition process", Entrepreneurship: Theory and Practice, Vol. 29 No. 4, pp. 451-472.

Macht, S. and Robinson, J. (2009), "Do business angels benefit their investee companies?", International Journal of Entrepreneurial Behavior and Research, Vol. 15 No. 2, pp. 187-208.

Macht, S.A. and Weatherston, J. (2014), "The benefits of online crowdfunding for fund-seeking business ventures", Strategic Change, Vol. 23 Nos 1-2, pp. 1-14.

MacMillan, I.C., Kulow, D.M. and Khoylian, R. (1989), "Venture capitalists' involvements in their investments: extent and performances”, Journal of Business Venturing, Vol. 4 No. 1, pp. 27-47.

Maine, E., Soh, P.H. and Santos, N. (2015), "The role of entrepreneurial decision-making in opportunity creation and recognition", Technovation, Vols 39-40, pp. 53-72.

Massolution (2016), Crowdfunding Industry Report 2015-2016, available at: Crowdsourcing.org (http:// www.crowdsourcing.org/editorial/global-crowdfunding-market-to-reach-344b-in2015-predictsmassolutions-2015cf-industry-report/45376).

Mauer, R., Neergaard, H. and Linstad, A.K. (2017), "Self-efficacy: conditioning the entrepreneurial mindset”, in Brännback, M. and Carsrud, A. (Eds), Revisiting the Entrepreneurial Mind, International Studies in Entrepreneurship, Springer, Cham, Vol. 35, pp. 293-317.

McGee, J.E. and Peterson, M. (2019), "The long-term impact of entrepreneurial self-efficacy and entrepreneurial orientation on venture performance", Journal of Small Business Management, Vol. 57 No. 3, pp. 720-737.

McGee, J.E., Peterson, M., Mueller, S.L. and Sequeira, J.M. (2009), "Entrepreneurial self-efficacy: refining the measure", Entrepreneurship: Theory and Practice, Vol. 33 No. 4, pp. 965-988.

McGrath, R.G. and MacMillan, I.C. (2000), The Entrepreneurial Mindset, Harvard Business School Press, MA: Boston.

McKenny, A.F., Allison, T.H., Ketchen, D.J., Short, J.C. and Ireland, R.D. (2017), "How should crowdfunding research evolve? A survey of the entrepreneurship theory and practice editorial board", Entrepreneurship: Theory and Practice, Vol. 41 No. 2, pp. 291-304. 
McMullen, J.S. and Shepherd, D.A. (2006), "Entrepreneurial action and the role of uncertainty in the theory of the entrepreneur", Academy of Management Review, Vol. 31 No. 1, pp. 132-152.

Meyer, C. (2019), "Social finance and the commons paradigm: exploring how community-based innovations transform finance for the common good", Management Decision, Vol. 58 No. 4, pp. 786-796.

Miao, C., Qian, S. and Ma, D. (2017), "The relationship between entrepreneurial self-efficacy and firm performance: a meta-analysis of main and moderator effects", Journal of Small Business Management, Vol. 55 No. 1, pp. 87-107.

Mochkabadi, K. and Volkmann, C.K. (2018), "Equity crowdfunding: a systematic review of the literature", Small Business Economics, pp. 1-44.

Mollick, E. (2014), "The dynamics of crowdfunding: an exploratory study", Journal of Business Venturing, Vol. 29 No. 1, pp. 1-16.

Neneh, B.N. (2019), "From entrepreneurial alertness to entrepreneurial behavior: the role of trait competitiveness and proactive personality", Personality and Individual Differences, Vol. 138 No. 1, pp. 273-279.

Obschonka, M., Hakkarainen, K., Lonka, K. and Salmela-Aro, K. (2017), "Entrepreneurship as a twenty-first century skill: entrepreneurial alertness and intention in the transition to adulthood”, Small Business Economics, Vol. 48, pp. 487-501.

Patel, P.C. (2019), "Opportunity related absorptive capacity and entrepreneurial alertness", International Entrepreneurship and Management Journal, Vol. 15, pp. 63-73.

Pellegrini, M. and Ciappei, C. (2015), "Ethical judgment and radical business changes: the role of entrepreneurial perspicacity", Journal of Business Ethics, Vol. 128, pp. 769-788.

Piva, E. and Rossi-Lamastra, C. (2018), "Human capital signals and entrepreneurs' success in equity crowdfunding”, Small Business Economics, Vol. 51, pp. 667-686.

Podsakoff, P.M., MacKenzie, S.B. and Podsakoff, N.P. (2012), "Sources of method bias in social science research and recommendations on how to control it", Annual Review of Psychology, Vol. 63, pp. 539-569.

Polzin, F., Toxopeus, H. and Stam, E. (2018), "The wisdom of the crowd in funding. Information heterogeneity and social networks of crowdfunders", Small Business Economics, Vol. 50 No. 2, pp. 251-273.

Pratono, A.H. and Mahmood, R. (2015), "Entrepreneurial orientation and firm performance: how can micro, small and medium-sized enterprises survive environmental turbulence?", Pacific Science Review B: Humanities and Social Sciences, Vol. 1, No. 2, pp. 85-91.

Pryor, C., Webb, J.W., Ireland, R.D. and Ketchen, D.J. (2016), "Toward an integration of the behavioral and cognitive influences on the entrepreneurship process", Strategic Entrepreneurship Journal, Vol. 10, pp. 21-42.

Ravand, H. and Baghaei, P. (2016), "Partial least squares structural equation modeling with R", Practical Assessment, Research and Evaluation, Vol. 21, No. 11, pp. 1-16.

Ray, S., Danks, N. and Velasquez Estrada, J.M. (2019), "Seminr: domain-specific language for building PLS structural equation models", R Package Version 1.0.0, available at: https://CRAN.R-project. org $/$ package $=$ seminr.

Reed, R., Storrud-Barnes, S. and Jessup, L. (2012), "How open innovation affects the drivers of competitive advantage: trading the benefits of IP creation and ownership for free invention", Management Decision, Vol. 50 No. 1, pp. 58-73.

Reinartz, W., Haenlein, M. and Henseler, J. (2009), "An empirical comparison of the efficacy of covariance-based and variance-based SEM", International Journal of Research in Marketing, Vol. 26 No. 4, pp. 332-344.

Renko, M., Shrader, R. and Simon, M. (2012), "Perception of entrepreneurial opportunity: a general framework", Management Decision, Vol. 50 No. 7, pp. 1233-1251.
Exploring entrepreneurial characteristics in $\mathrm{ECF}$ 
Rosenzweig, P. (2013), "What makes strategic decisions different?", Harvard Business Review, Vol. 91 No. 11, pp. 88-93.

Rossi, A. and Vismara, S. (2018), "What do crowdfunding platforms do? A comparison between investment-based platforms in Europe", Eurasian Business Review, Vol. 8 No. 1, pp. 93-118.

Roundy, P.T., Harrison, D.A., Khavul, S., Pérez-Nordtvedt, L. and McGee, J.E. (2018), "Entrepreneurial alertness as a pathway to strategic decisions and organizational performance", Strategic Organization, Vol. 16 No. 2, pp. 192-226.

Sadler-Smith, A. (2004), "Cognitive style and the management of small and medium-sized enterprises", Organization Studies, Vol. 25 No. 2, pp. 155-181.

Sahaym, A., Datta, A.A. and Brooks, S. (2019), "Crowdfunding success through social media: going beyond entrepreneurial orientation in the context of small and medium-sized enterprises", Journal of Business Research, (In press), available at: https://doi.org/10.1016/j.jbusres.2019. 09.026.

Sanchez, G., Trinchera, L. and Russolillo, G. (2017), "Plspm: tools for partial least squares path modeling (PLS-PM)", $R$ Package Version 0.4.9, available at: https://CRAN.R-project.org/ package $=$ plspm.

Sarkar, M.B., Echambadi, R.A.J. and Harrison, J.S. (2001), "Alliance entrepreneurship and firm market performance", Strategic Management Journal, Vol. 22 Nos 6-7, pp. 701-711.

Sashi, C. (2012), "Customer engagement, buyer-seller relationships, and social media", Management Decision, Vol. 50 No. 2, pp. 253-272.

Sassetti, S., Cavaliere, V. and Lombard, S. (2019), "Entrepreneurial success: a theoretical contribution linking affect and cognition", Caputo and Pellegrini, The Anatomy of Entrepreneurial Decisions Past, Present and Future Research Directions, Contributions to Management Science, Springer Nature Switzerland AG, Cham, pp. 57-77.

Saunders, M.N. and Lewis, P. (2012), Doing Research in Business and Management: An Essential Guide to Planning Your Project, Pearson, Harlow.

Schjoedt, L. and Craig, J. (2017), "Development and validation of a unidimensional domain-specific entrepreneurial self-efficacy scale", International Journal of Entrepreneurial Behavior and Research, Vol. 23 No. 1, pp. 98-113.

Schmitt, A., Rosing, K., Zhang, S.X. and Leatherbee, M. (2018), "A dynamic model of entrepreneurial uncertainty and business opportunity identification: exploration as a mediator and entrepreneurial self-efficacy as a moderator", Entrepreneurship: Theory and Practice, Vol. 42 No. 6, pp. 835-859.

Schmutzler, J., Andonova, V. and Diaz-Serrano, L. (2019), "How context shapes entrepreneurial selfefficacy as a driver of entrepreneurial intentions: a multilevel approach", Entrepreneurship: Theory and Practice, Vol. 43 No. 5, pp. 880-920.

Schwienbacher, A. (2018), "Entrepreneurial risk-taking in crowdfunding campaigns", Small Business Economics, Vol. 51, pp. 843-859.

Schwienbacher, A. and Larralde, B. (2012), "Crowdfunding of small entrepreneurial ventures", in Cummings, D. (Ed.), The Oxford Handbook of Entrepreneurial Finance, Oxford University Press, Oxford, pp. 369-391.

Shahab, Y., Chengang, Y., Arbizu, A. and Haider, M. (2019), "Entrepreneurial self-efficacy and intention: do entrepreneurial creativity and education matter?", International Journal of Entrepreneurial Behavior and Research, Vol. 25 No. 2, pp. 259-280.

Shane, S. (2000), "Prior knowledge and the discovery of entrepreneurial opportunities", Organization Science, Vol. 11 No. 4, pp. 448-469.

Shane, S. and Venkataraman, S. (2000), "The promise of entrepreneurship as a field of research", Academy of Management Review, Vol. 25 No. 1, pp. 217-226. 
Sharma, L. (2019), "A systematic review of the concept of entrepreneurial alertness", Journal of Entrepreneurship in Emerging Economies, Vol. 11 No. 2, pp. 217-233.

Shehu, A.M. and Mahmood, R. (2014), "Influence of entrepreneurial orientation and business environment on small and medium firm performance: a PLS approach", Advances in Management and Applied Economics, Vol. 4 No. 4, pp. 101-114.

Shepherd, D.A. and Patzelt, H. (2017), Trailblazing in Entrepreneurship, Palgrave Macmillan, Cham.

Shepherd, D.A., Williams, T.A. and Patzelt, H. (2015), "Thinking about entrepreneurial decision making: review and research agenda", Journal of Management, Vol. 41 No. 1, pp. 11-46.

Stevenson, R.M., Ciuchta, M.P., Letwin, C., Dinger, J.M. and Vancouver, J.B. (2019), "Out of control or right on the money? Funder self-efficacy and crowd bias in equity crowdfunding", Journal of Business Venturing, Vol. 34 No. 2, pp. 348-367.

Stroe, S., Parida, V. and Wincent, J. (2018), "Effectuation or causation: an fsQCA analysis of entrepreneurial passion, risk perception, and self-efficacy", Journal of Business Research, Vol. 89, pp. 265-272.

Tang, J., Kacmar, K.M. and Busenitz, L. (2012), "Entrepreneurial alertness in the pursuit of new opportunities", Journal of Business Venturing, Vol. 27 No. 1, pp. 77-94.

Technavio (2018), Global Crowdfunding Market 2018-2022, available at: https:/www.technavio.com/ report/crowdfunding-market-industry-analysis.

Tenenhaus, M., Vinzi, V.E., Chatelin, Y.M. and Lauro, C. (2005), "PLS path modeling”, Computational Statistics and Data Analysis, Vol. 48 No. 1, pp. 159-205.

Ucbasaran, D., Westhead, P. and Wright, M. (2008), "Opportunity identification and pursuit: does an entrepreneur's human capital matter?”, Small Business Economics, Vol. 30 No. 2, pp. 153-173.

Ucbasaran, D., Westhead, P. and Wright, M. (2009), "The extent and nature of opportunity identification by experienced entrepreneurs", Journal of Business Venturing, Vol. 24 No. 2, pp. 99-115.

Valliere, D. (2013), "Towards a schematic theory of entrepreneurial alertness", Journal of Business Venturing, Vol. 28 No. 3, pp. 430-442.

Van Den Bosch, F.A.J., Volberda, H.W. and De Boer, M. (1999), "Coevolution of firm absorptive capacity and knowledge environment: organizational forms and combinative capabilities", Organization Science, Vol. 10 No. 5, pp. 551-568.

Vermeulen, P.A.M. and Curseu, P.L. (2008), Entrepreneurial Strategic Decision Making: A Cognitive Perspective, Edward Elgar, Cheltenham.

Vismara, S. (2016), "Equity retention and social network theory in equity crowdfunding", Small Business Economics, Vol. 46 No. 4, pp. 579-590.

Vismara, S. (2018), "Information cascades among investors in equity crowdfunding", Entrepreneurship: Theory and Practice, Vol. 42 No. 3, pp. 467-497.

Vulkan, N., Åstebro, T.B. and Sierra, M.F. (2016), "Equity crowdfunding: a new phenomena”, Journal of Business Venturing Insights, Vol. 5 No. C, pp. 37-49.

Wald, A., Holmesland, M. and Efrat, K. (2019), "It is not all about money: obtaining additional benefits through equity crowdfunding", The Journal of Entrepreneurship, Vol. 28 No. 2, pp. 270-294.

Wang, Y., Ellinger, A. and Jim Wu, Y. (2013), "Entrepreneurial opportunity recognition: an empirical study of R\&D personnel", Management Decision, Vol. 51 No. 2, pp. 248-266.

Welter, C. and Alvarez, S. (2015), "The state of opportunities: clarifying the transitions between opportunity types", Management Decision, Vol. 53 No. 7, pp. 1398-1411.

$\mathrm{Xu}$, Y., Ribeiro-Soriano, D. and Gonzalez-Garcia, J. (2015), "Crowdsourcing, innovation and firm performance”, Management Decision, Vol. 53 No. 6, pp. 1158-1169.

\section{entrepreneurial characteristics in $\mathrm{ECF}$}

Exploring 
$\mathrm{MD}$

59,5

1022
Yagnik, A. and Chandra, Y. (2019), Using Creativity to Defeat Fear and Manage Ambiguity for Enhancing Entrepreneurial Decisions, Caputo and Pellegrini, The Anatomy of Entrepreneurial Decisions Past, Present and Future Research Directions, Contributions to Management Science, Springer Nature Switzerland AG, pp. 9-28.

Zhao, H., Hills, G.E. and Seibert, S.E. (2005), "The mediating role of self-efficacy in the development of entrepreneurial intentions", Journal of Applied Psychology, Vol. 90 No. 6, pp. 1265-1272.

Zheng, H., Li, D., Wu, J. and Xu, Y. (2014), "The role of multidimensional social capital in crowdfunding: a comparative study in China and US", Information and Management, Vol. 51 No. 4, pp. 488-496.

Zheng, H., Xu, B., Wang, T. and Chen, D. (2017), "Project implementation success in reward-based crowdfunding: an empirical study", International Journal of Electronic Commerce, Vol. 21 No. 3, pp. 424-448.

Zollo, L., Faldetta, G., Pellegrini, M.M. and Ciappei, C. (2017), "Reciprocity and gift-giving logic in NPOs", Journal of Managerial Psychology, Vol. 32 No. 7, pp. 513-526.

Zollo, L., Laudano, M.C., Boccardi, A. and Ciappei, C. (2019), "From governance to organizational effectiveness: the role of organizational identity and volunteers' commitment", Journal of Management and Governance, Vol. 23 No. 1, pp. 111-137. 
Appendix 1

List of abbreviations
Exploring entrepreneurial characteristics in $\mathrm{ECF}$

ECF

EDM

$\mathrm{VC}_{\mathrm{S}}$

$\mathrm{BA}_{\mathrm{s}}$

EA

ESE

PMK

NET

PR

$\mathrm{CCC}$

$\mathrm{COC}$

SS

$\mathrm{AC}$

EJ

OI

AON

PERF

PLS

SEM

VIF

$\mathrm{CMB}$

AVE
Equity Crowdfunding

Entrepreneurial Decision Making

Venture Capitalists

Business Angels

Entrepreneurial Alertness

Entrepreneurial Self Efficacy

Product and Market Knowledge

Networking

Promotion

Campaign Communication Characteristics

Campaign Offering Characteristics

Scanning and searching

Association and Connection

Evaluation and Judgment

Open Innovation

All Or Nothing (model)

Performance

Partial Least Squares

Structural equation modeling

Variance Inflation Factor

Common Method Bias

Average variance extracted 
$\mathrm{MD}$

59,5

\begin{tabular}{ll}
\hline $\mathbf{1 0 2 4}$ & Description \\
\hline Item & I have frequent interactions with others to acquire new information \\
SS1 & I always keep an eye out for new business ideas when looking for information \\
SS2 & I read news, magazines, or trade publications regularly to acquire new information \\
SS3 & I browse the internet every day \\
SS5 & I am an avid information seeker \\
SS6 & I am always actively looking for new information \\
AC1 & I see links between seemingly unrelated pieces of information \\
AC2 & I am good at "connecting dots" \\
AC3 & I often see connections between previously unconnected domains of information \\
EJ1 & I have a gut feeling for potential opportunities \\
EJ2 & I can distinguish between profitable opportunities and not-so-profitable opportunities \\
EJ3 & I have a knack for telling high-value opportunities apart from low-value opportunities \\
EJ4 & When facing multiple opportunities, I am able to select the good ones \\
ESE1 & I'm confident I'm successful at identifying new business opportunities \\
ESE2 & I'm confident I'm successful at creating new products \\
ESE3 & I'm confident I'm successful at thinking creatively \\
ESE4 & I'm confident I'm successful at commercialising an idea or new development \\
PMK1 & In ECF I look for learning new product/service features to consider \\
PMK2 & In ECF I look for feedback on the early-version of the product/service \\
PMK3 & In ECF I look for getting needed foreign country information \\
PMK4 & In ECF I look for getting market trends insights \\
PMK5 & In ECF I look for information about potential competitors and partners \\
NET1 & In ECF I look for connections with key industry players \\
NET2 & In ECF I look for contacts with investors to obtain additional financing \\
NET3 & In ECF I look for distribution contacts \\
NET4 & In ECF I look for connections to favour recruitment of key staff \\
PR1 & In ECF I look for leveraging crowd's contacts to help promote my business \\
PR2 & In ECF I look for backers acting as marketing channels \\
PR3 & In ECF I look for backers helping me in spreading the word through social media \\
&
\end{tabular}

\section{Corresponding author}

Mario Tani can be contacted at: mario.tani@unina.it

For instructions on how to order reprints of this article, please visit our website: 